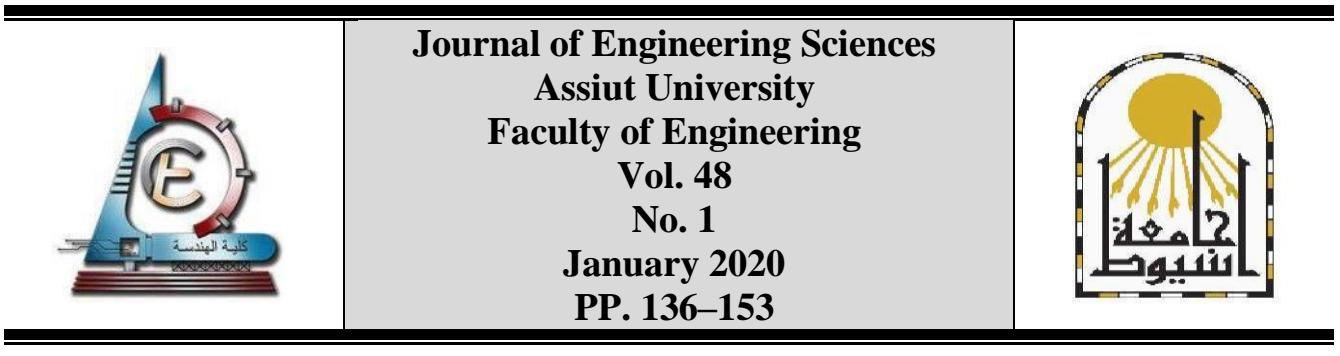

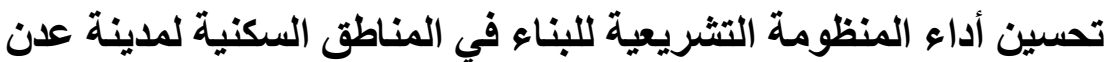

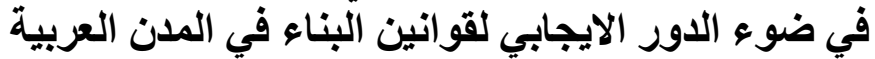 ابتسام عبدالله ناصر عمبر "، مجدي محمد رضوان، ممدوح علي يوسف الجئ قسم العمارة بكلية الهندسة - جامعة أسبوط
}

Received 22 July 2019; Accepted 4 August 2019

\section{ملخص}

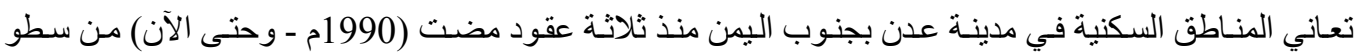

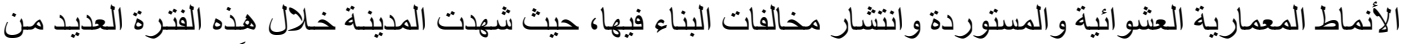

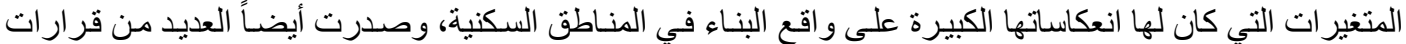

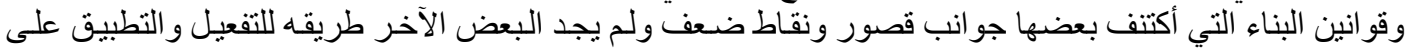

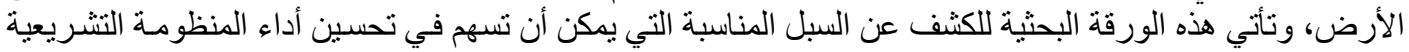

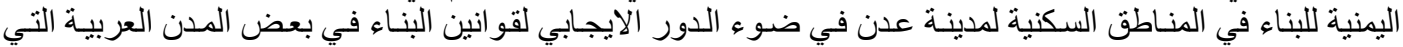

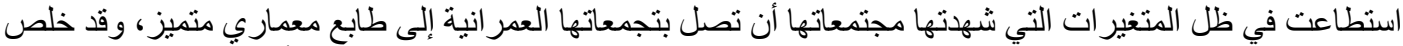

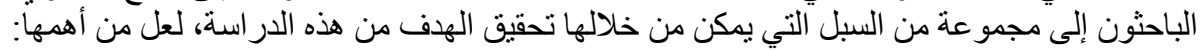

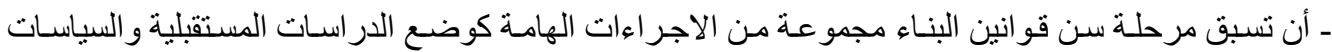

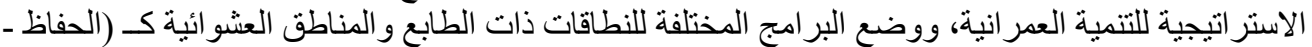

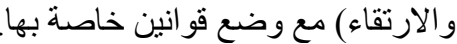

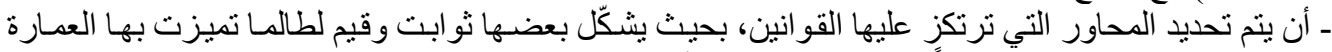

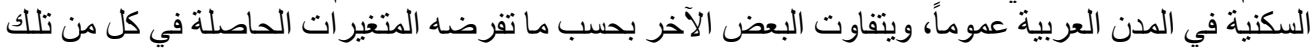
المدن ويتم تناو لها في تعديلات القو انين.

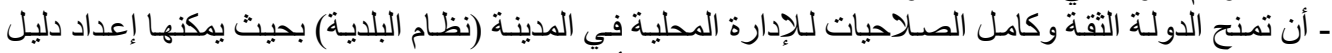

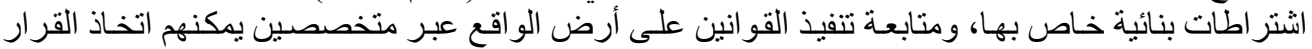

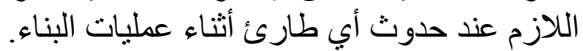

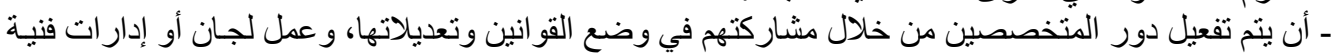

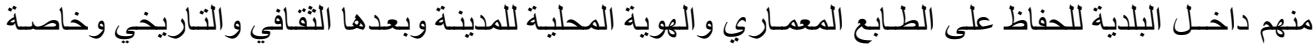

$$
\text { في حيها القديم (عدن القديمة). }
$$

وتتناول الورقة البحثية النقاط التالية:

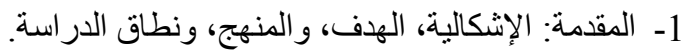

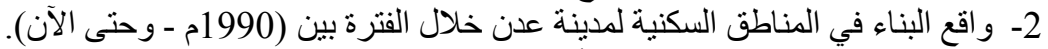

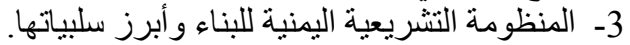

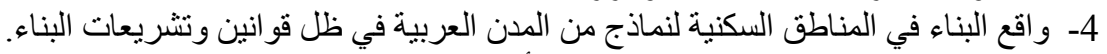
5- الدروس المستفادة من النماذج السابقة في تحسبن أداء المنظومة التشريعية للبناء في المناطق فئن السكنية لمدينة عند.

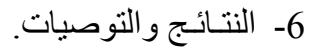


ابتسام عبداله ناصر عمبر - تحسين أداء المنظومة التشريعية للبناء في المناطق السكنية لمدينة عدن في ضوء.

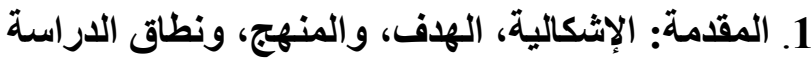

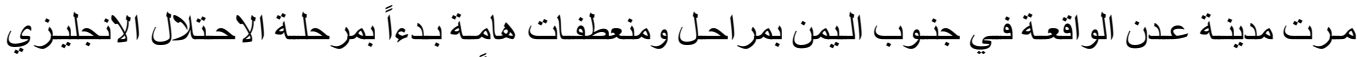

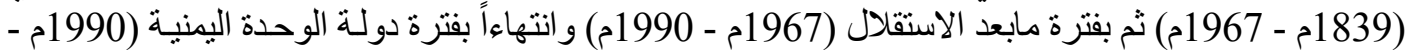

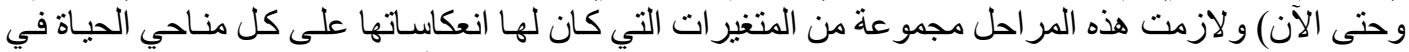

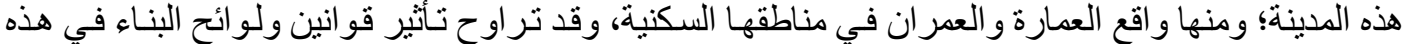

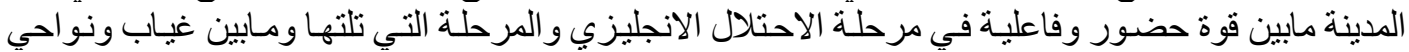

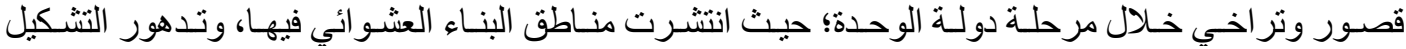

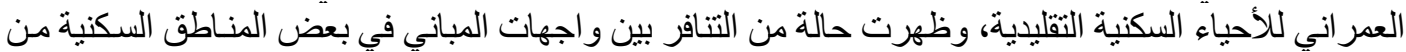

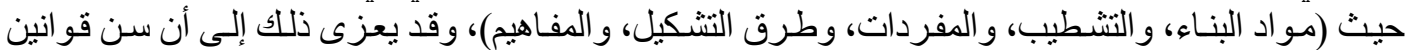

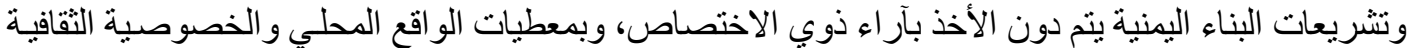

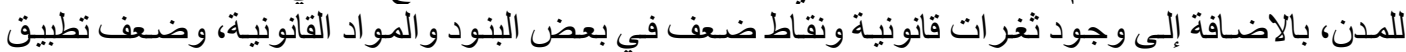

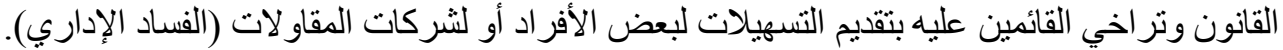

وتعتبر العمارة في المناطق السكنية لمدينة عدن نموذج مثيل لما تعانيه العمارة في المدن العربية من سطو

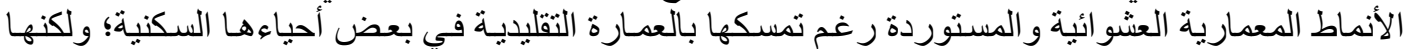

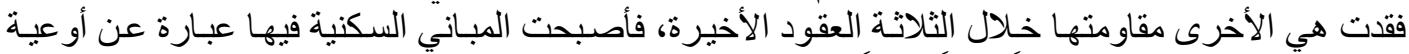

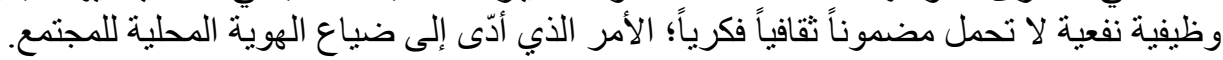

1.1. الإشكالبة

تتلخص إثكالية البحث في طر ح السبل المناسبة لتحسين أداء المنظومـة التشـريعية اليمنيـة للبنـاء بمـا يسهمح

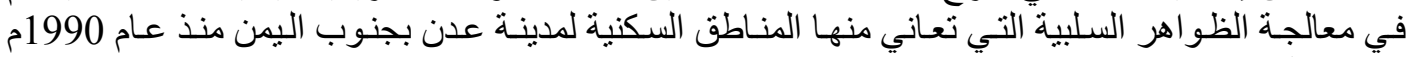
وحتى الآن؛ وذللك في ضوء الاستفادة من ايجابيات القو انين المناظرة لها في المدن العربية. ومن هذا المنطلق يمكن تشخيص أسئلة البحث على النحو التالي: ـ ماهي الظو اهر السلبية التي لازمت عمارة المناطق السكنية لمدينـة عدن منذ عـام 1990م وحتى الآن

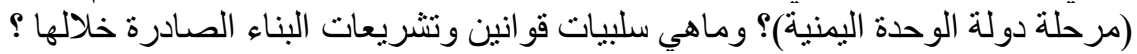

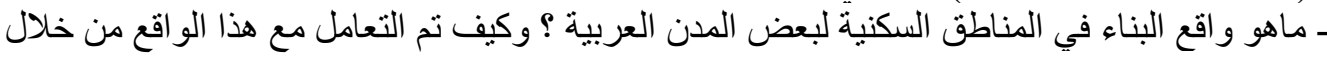

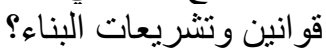
ـ ماهي المحاور التي ترنكز عليها قو انين وتشريعات البنـاء في المنـاطق السكنية لهذه المدن، ومـاهي

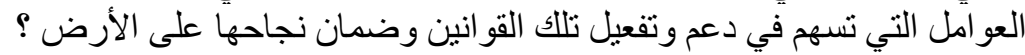
ليأتي بعد ذلك السؤال المحوري، وهو: ـ كيف يمكن الاستفادة من الدور الايجابي لقو انين البناء في المناطق السكنية للمدن العربية بمـا يسـهم في

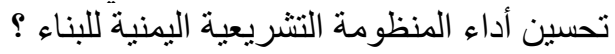

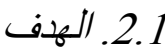

يهدف البحث إلى الكثف عن السبل التي يمكن أن تسهم في تحسين أداء المنظومة التشريعية اليمنيـة للبنـاء في المناطق السكنية لمدينة عدن في ضوء الآلئن الدور الايجابي لقو انين البناء في المدن العربية.

3.1

يتّبع البحث كل من المناهج البحثية التالية:

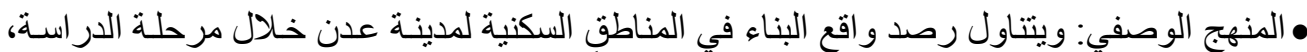

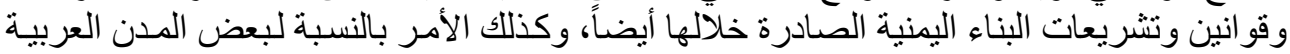
في ظل قو انين البناء التي مرت بهاء التها و التغيير ات المتلاحقة التي شهدتها. 
JES, Assiut University, Faculty of Engineering, Vol. 48, No. 1, January 2020, pp. 136-153

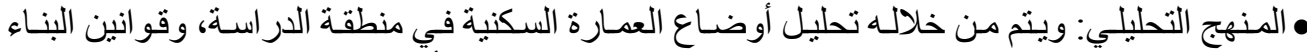

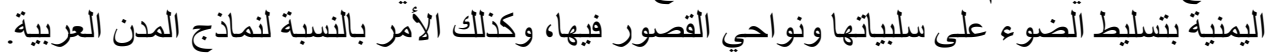

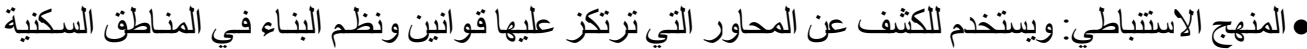

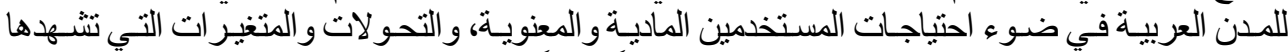

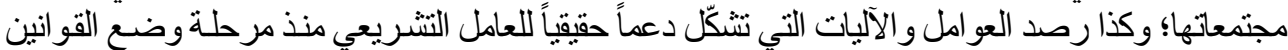

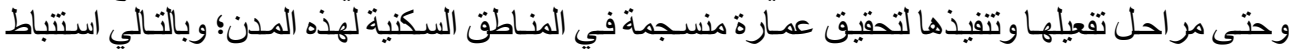

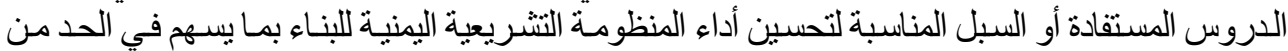
الظو الهر السليية داخل المناطق السكنية لمدينة عدن ويحقق النظام الاستدامة والقيم الاجتماعية والثقافية للمجتمع.

$$
\text { 4.1 4.1 نطاق الدراسة }
$$

ـ النطاق المكاني: يركز البحث على در اسة واقع البناء في المناطق السكنية لمدينة عدن (بجنوب اليمن)

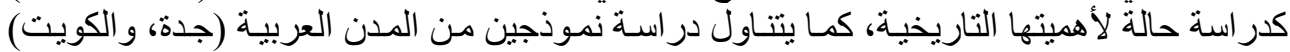

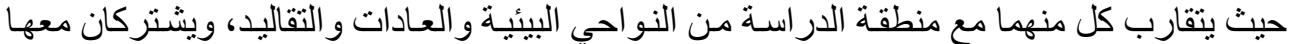

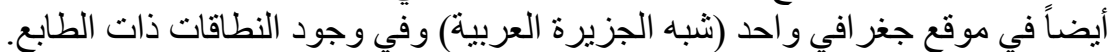

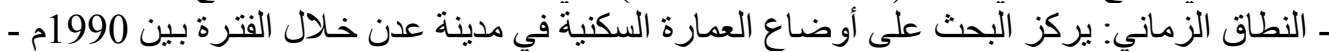

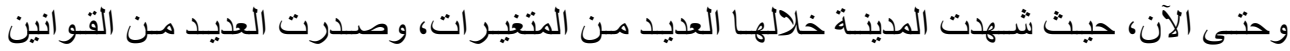

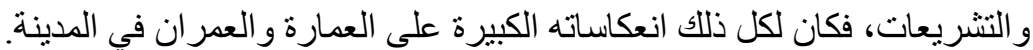

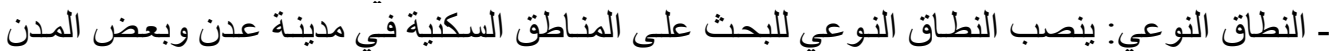

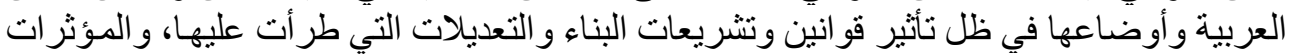
و التغير ات التي شهدتها كل منها.

\section{2. واقع البناء في المناطق السكنية لمدينة عدن خلال القترة بين 1990م - وحتى الآن}

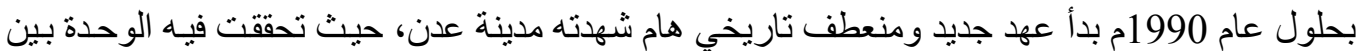

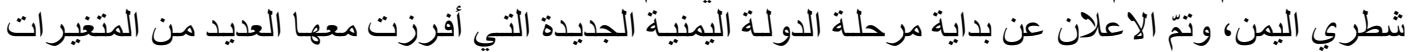

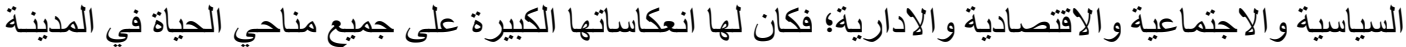

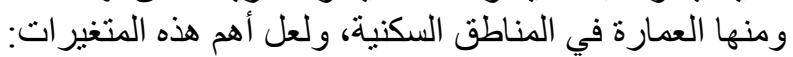

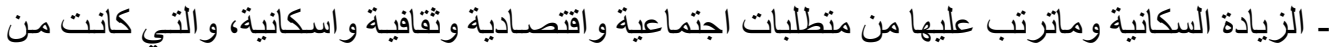

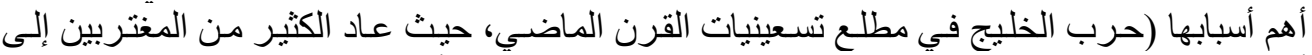

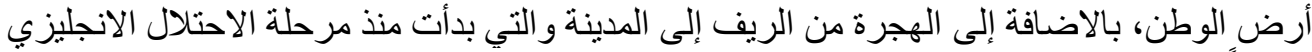

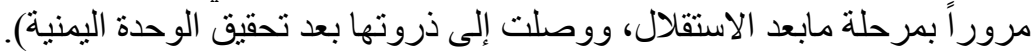

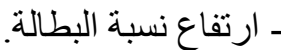

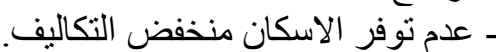

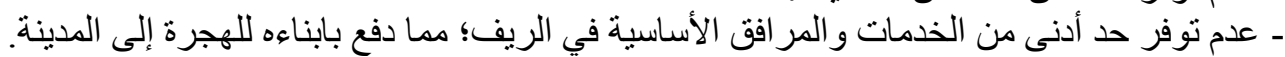

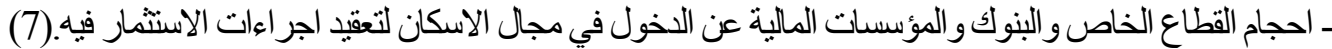
- ضعف الرقابة الرسمية في الحد من عملية البناء العشو الئي.

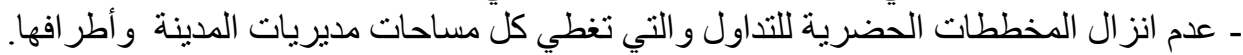

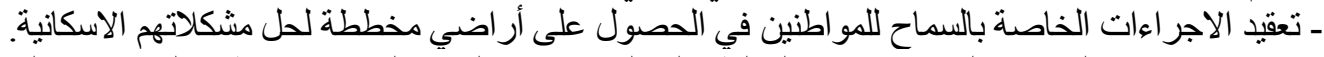

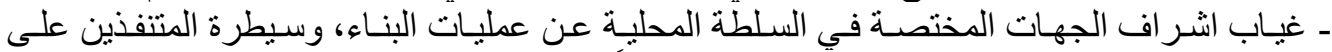

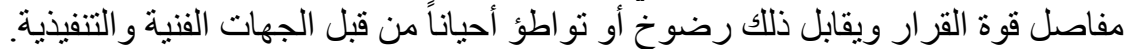

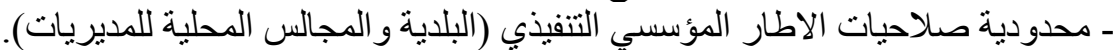

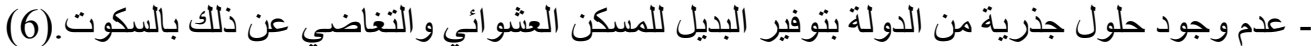

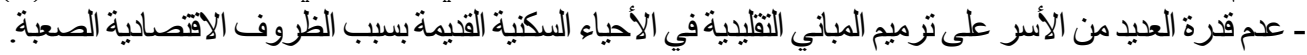


ابتسام عبداله ناصر عمبر - تحسين أداء المنظومة التشريعية للبناء في المناطق السكنية لمدينة عدن في ضوء.

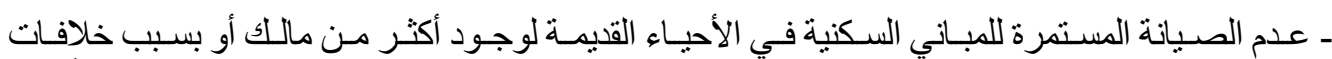

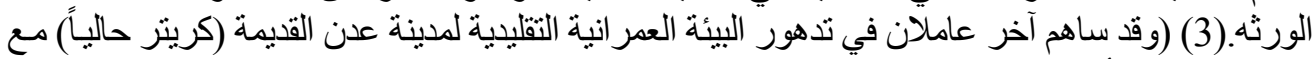

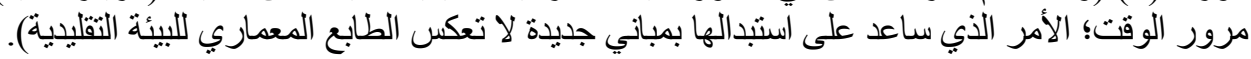

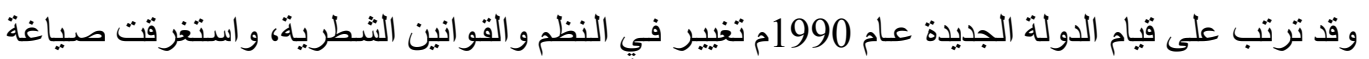

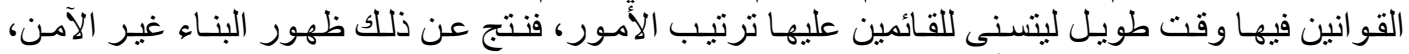
و وناطق البناء العشوائي* التي أمتدت لتقضي على التى المناطق المسطحة و المنحدرات الجبلية القريبة من منساطق

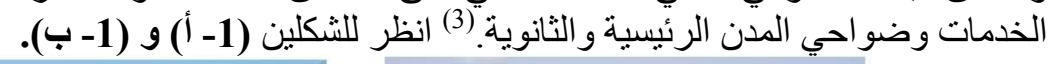

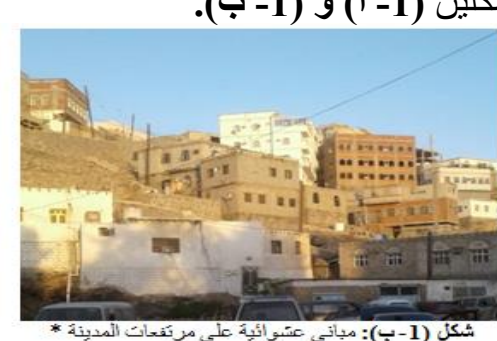

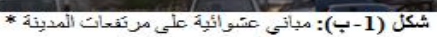

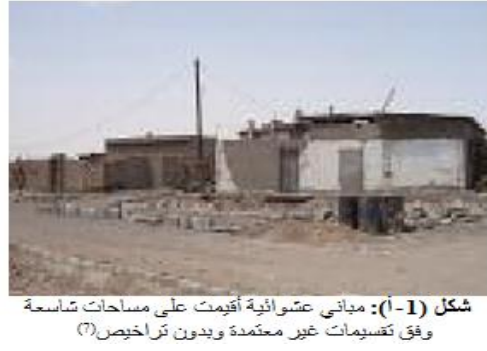

و الجدير بالذكر أنه في عام 1996م تم تطوير مخطط مدينة عدن الكبرى الذي تمّ وضعه في مرحلة سـابقة

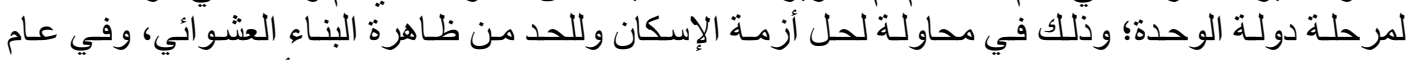

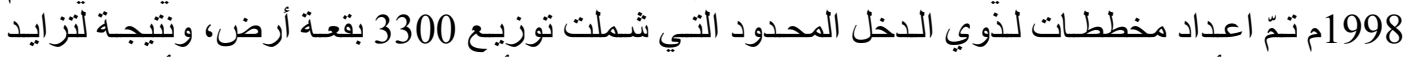

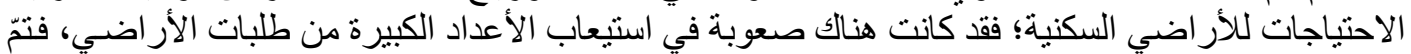

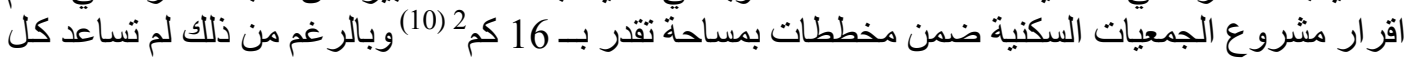
هذه الاجر اءات في معالجة الوضع المزري الذي وصل إليه واقع البناء في المناطق السكنية لمدينة عدن.

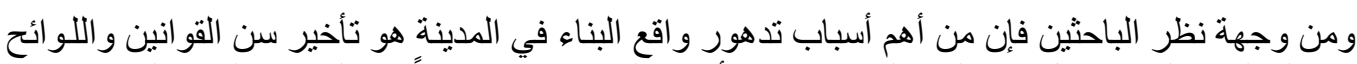

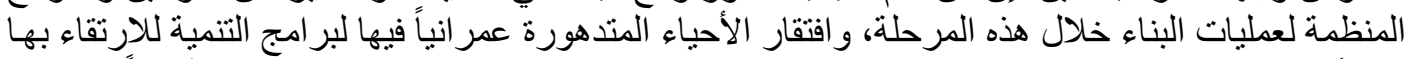

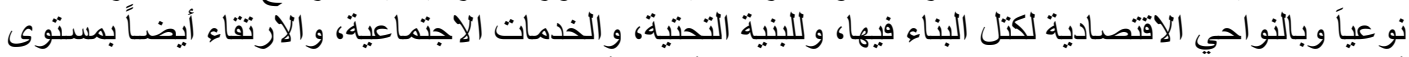

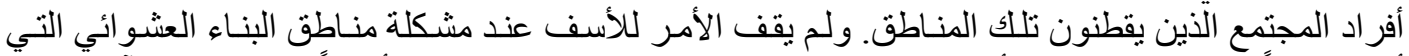

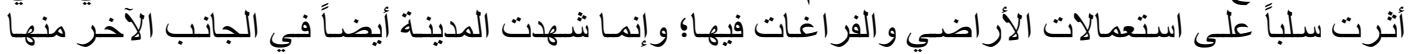

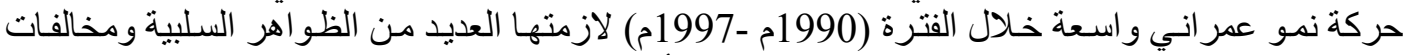

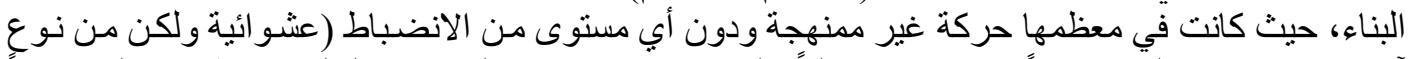

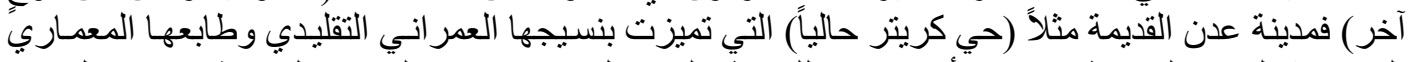

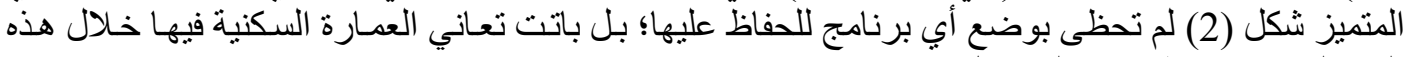

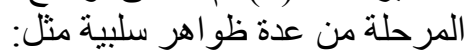

ـ عدم الالتز ام بخط تنظيم البناء في أحياءها السكنية المختلفة.

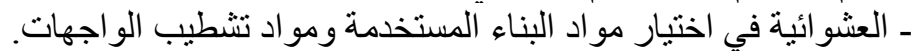

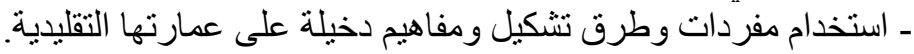

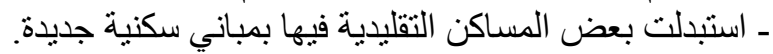

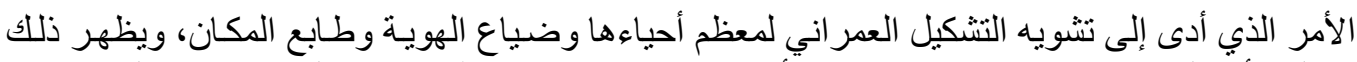

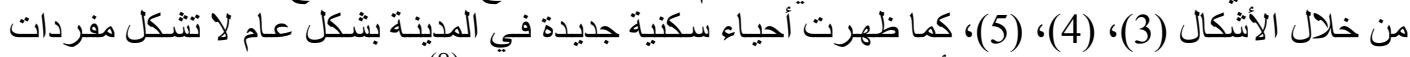

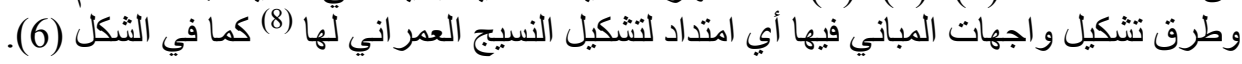




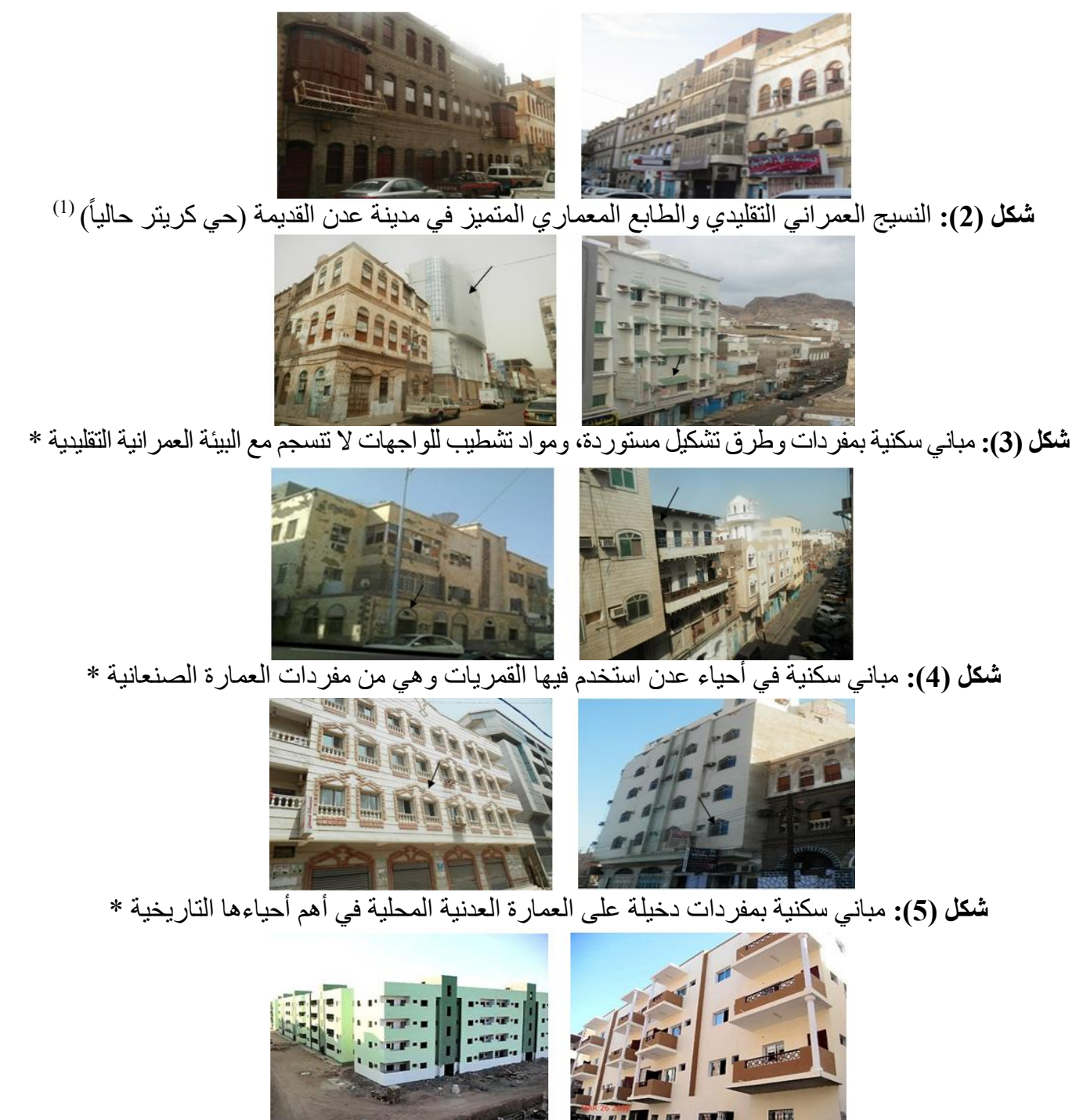

شكل (6): عمار ات سكنية بمفردات سطحية معاصرة من من أحد المشـاريع السكنية الخاصـة (مدينة إنما) في مدينة

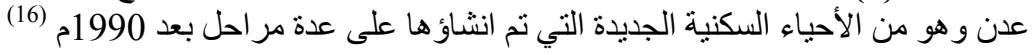

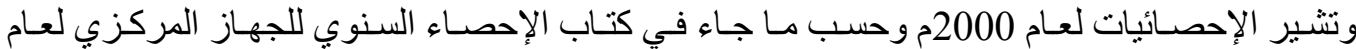

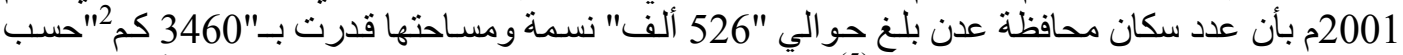

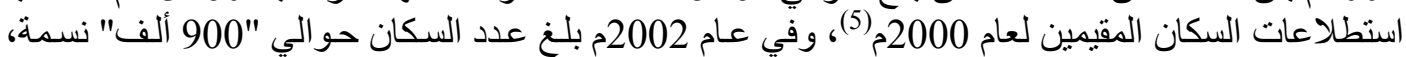

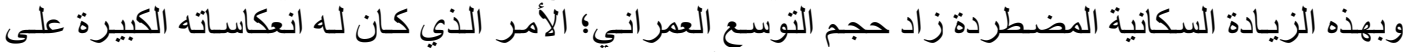

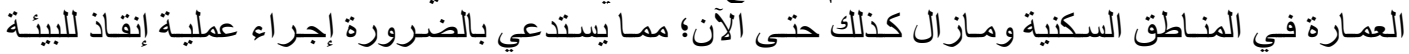

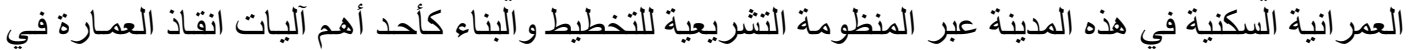

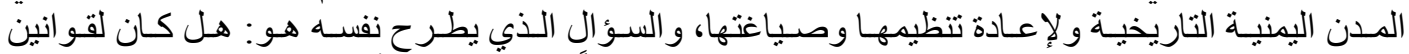

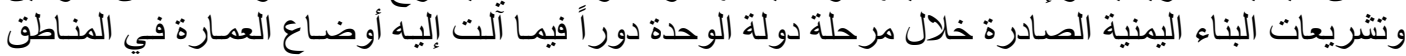


ابتسام عبداله ناصر عمبر - تحسين أداء المنظومة التشريعية للبناء في المناطق السكنية لمدينة عدن في ضوء.

السكنية لمدينـة عدن (منطقة الدر اسـة)؟ وللإجابـة على هذا السؤال وجب على البـاحثين رصد هذه القوانين

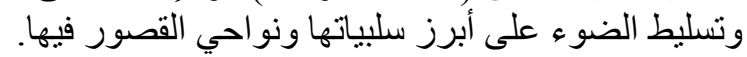

\section{3. المنظومة التشريعية اليمنية للبناء وأبرز سلبياتها}

صدرت في عهد دولة الوحدة (1990م ـ الآن) مجمو عة من قرار ات وقو انين التخطبطو البناء للمباني السكنية في

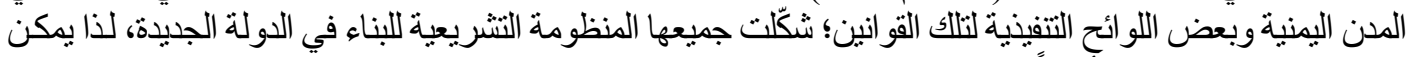

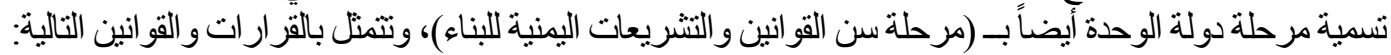
ـ قر ار وزاري رقم (23) لسنة 1994م بشأن لائحة مخالفات التخطيط و البناء.

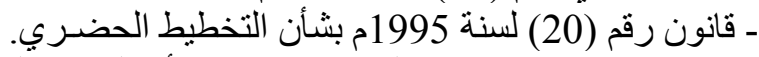

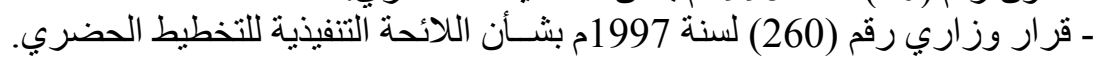

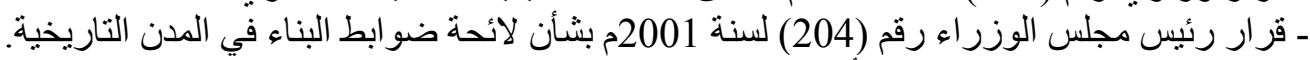

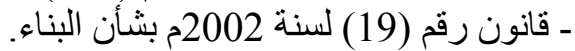
ـ قر ار مجلس الوزر اءؤ رقدم (351) لسنة 2008م بشأن اللائحة التنفيذية لتنظيم أعمال البناء.

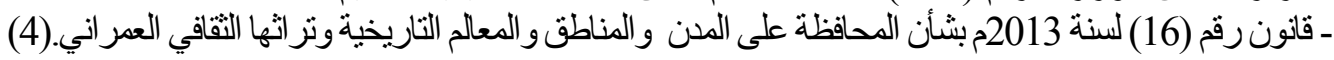

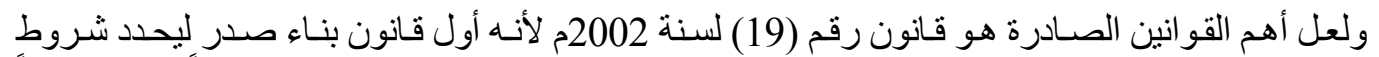

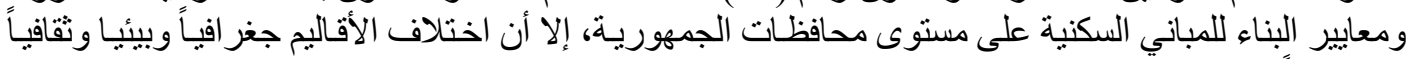

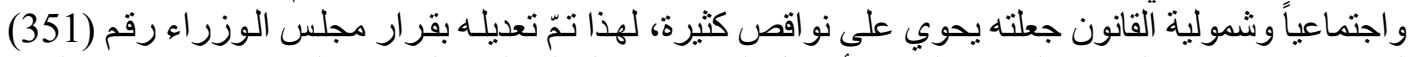

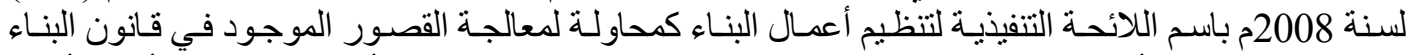

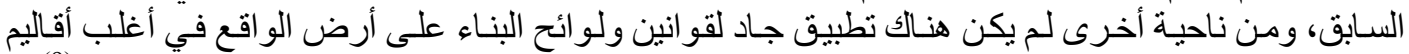

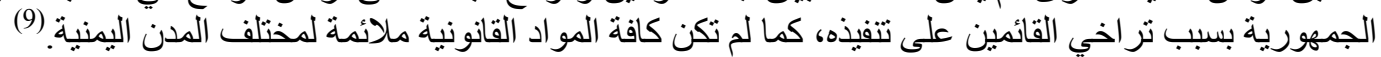
ويرى الباحثون أيضاً من خلال مر اجعة كل القرار ات والقو انين؛ أن أبرز سلييات المنظومة التشريعية البينية للبناء ما يلي:

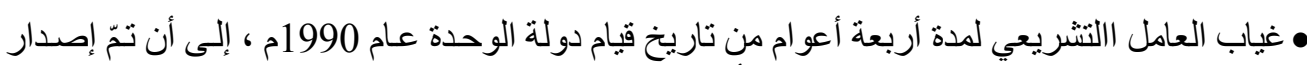

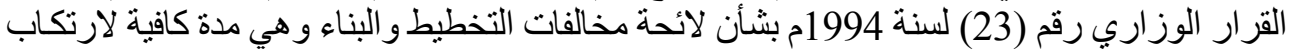

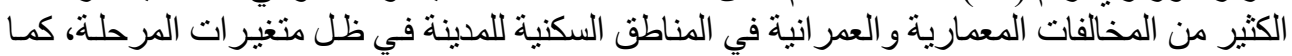

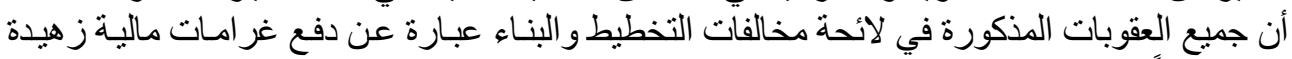

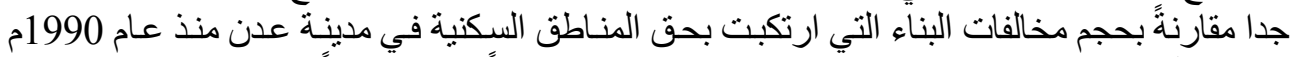

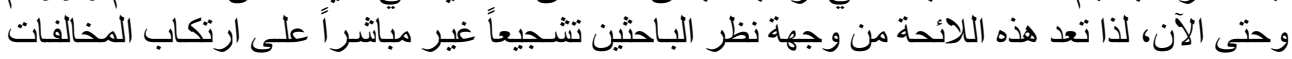

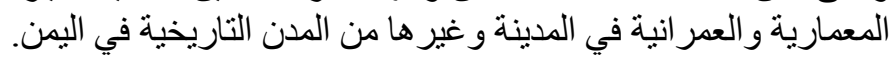

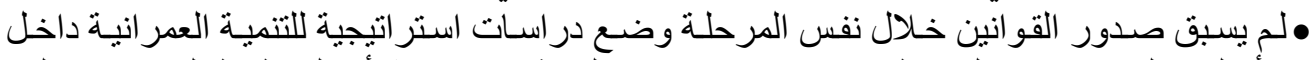

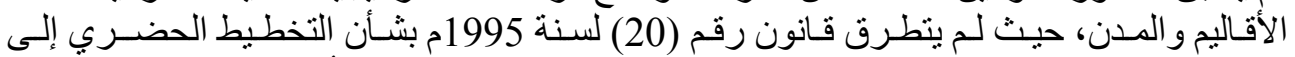

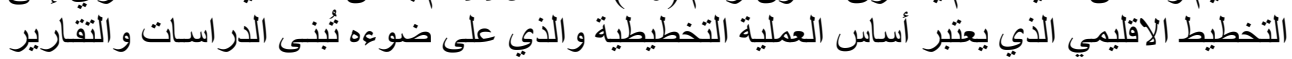

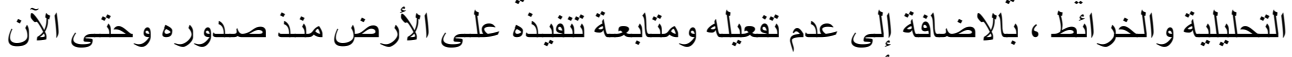

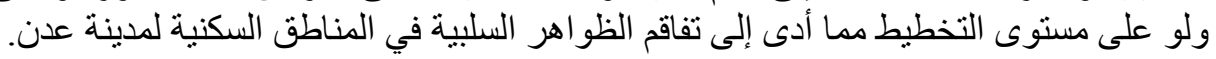

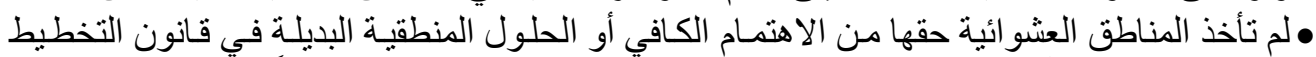

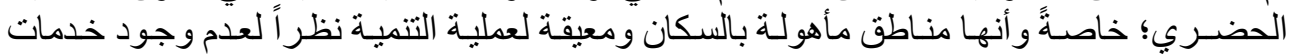

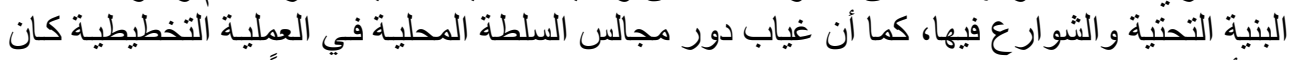

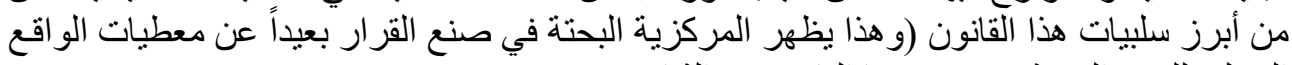

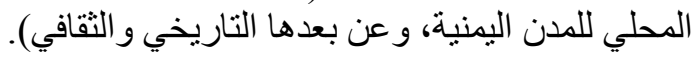

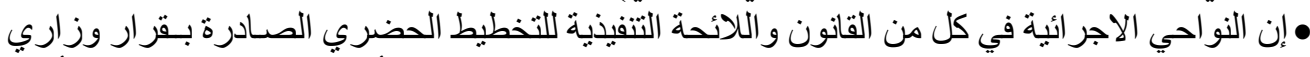

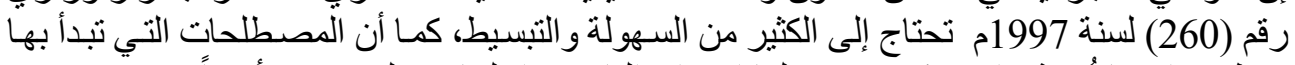

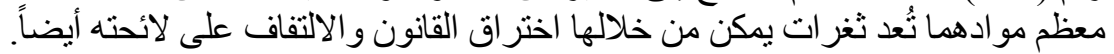




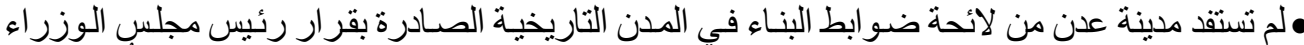

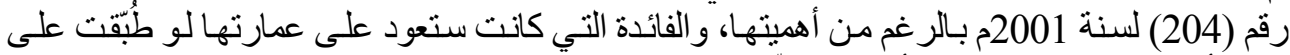

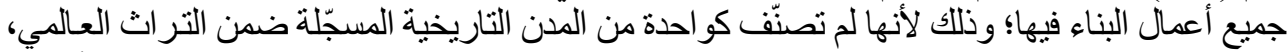

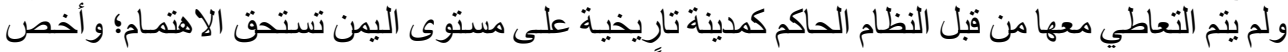

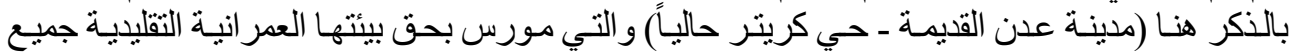

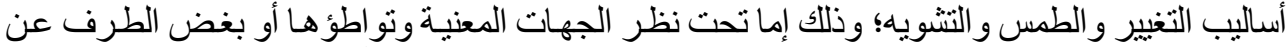

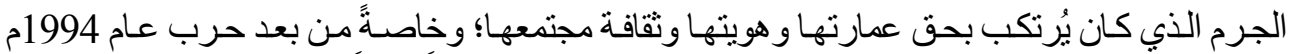

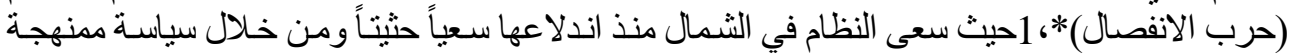

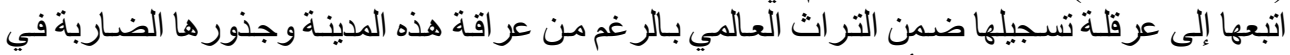

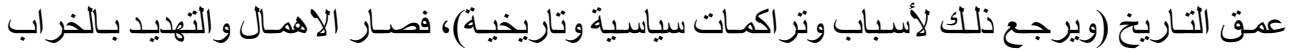

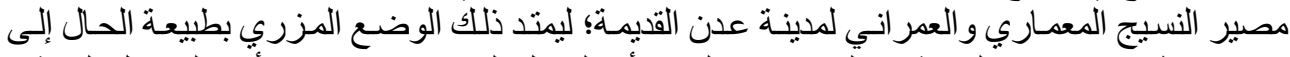

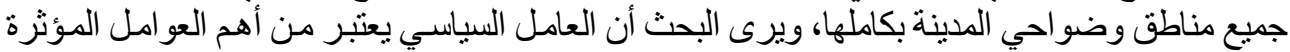

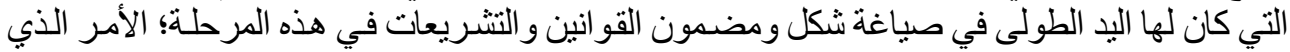

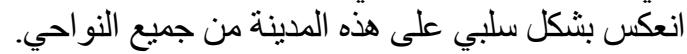

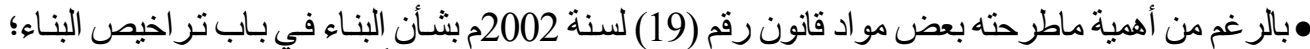

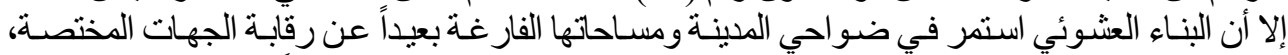

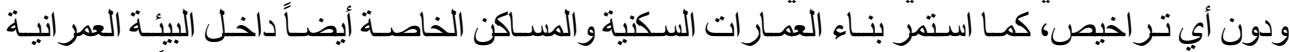

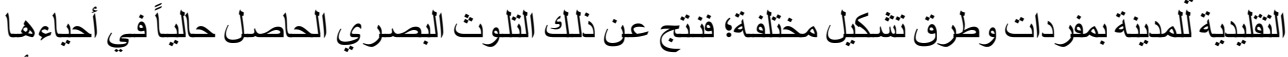

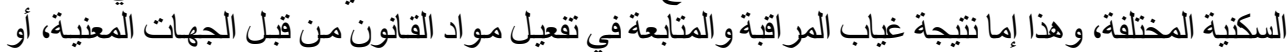

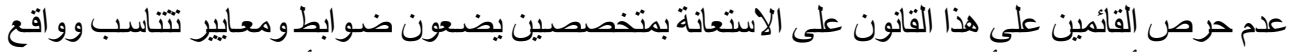

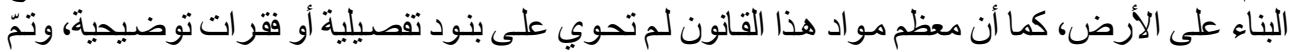

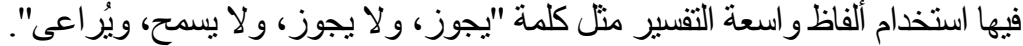

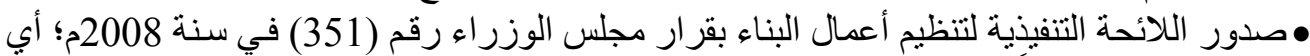

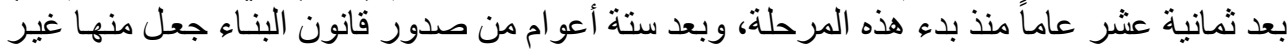

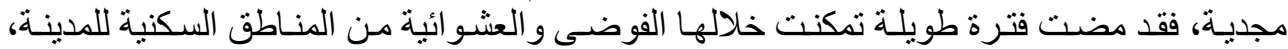

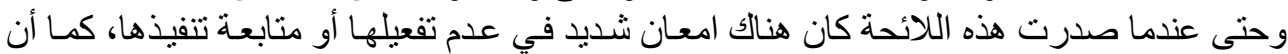

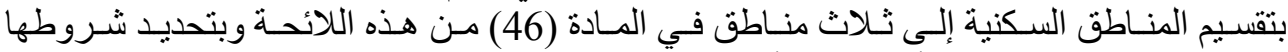

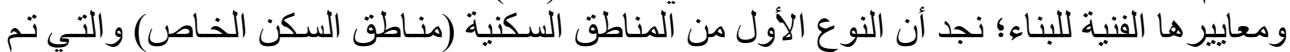

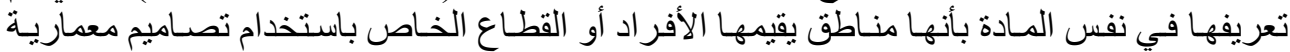

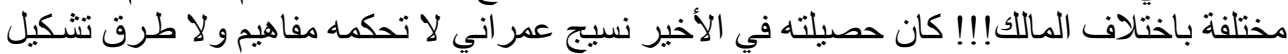

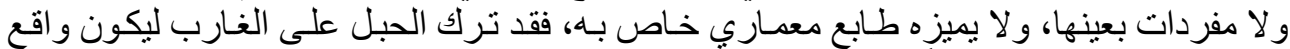

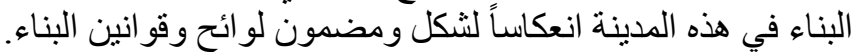

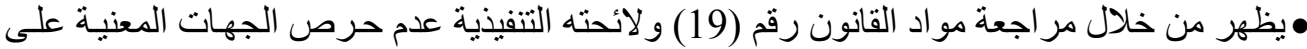

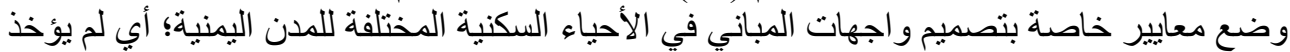
في الاعتبار المعطيات المحلية والمرجية واهية الثقافية و التاريخية لكل مدينة.

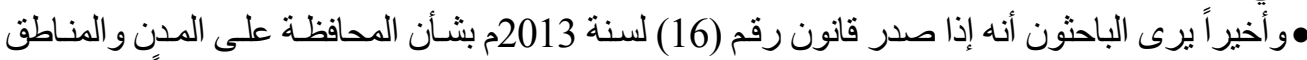

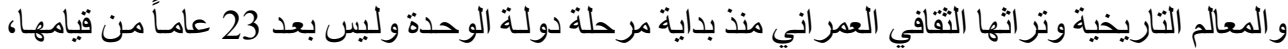

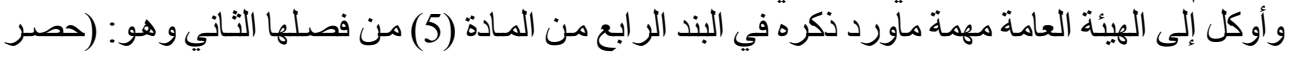

* حرب عام 1994م (حرب الانفصال): حرب قامت في صيف 1994م بين شمال اليمن وجنوبه، وذلك عندما أعلن رئيس دولة الئل

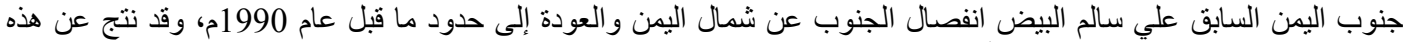

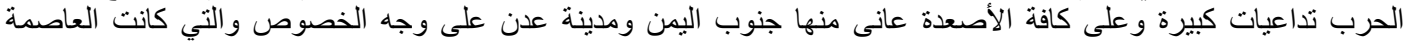
السياسية له قبل قيام دولة الوحدة (الجمهورية اليمنية). 
ابتسام عبدالهه ناصر عمبر - تحسين أداء المنظومة التشريعبة للبناء في المناطق السكنية لمدينة عدن في ضوء.

وتصنيف وتوثيق وتقييم المدن و المناطق والمعـالم التاريخيـة واقتر اح تسـيلها في السجل و إير از هـا على

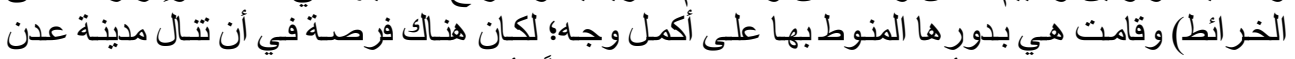

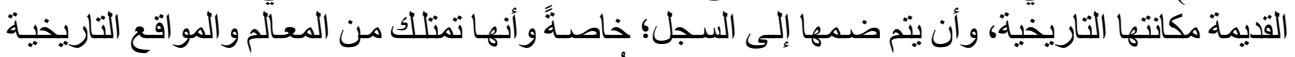

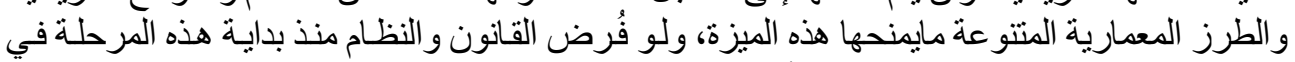

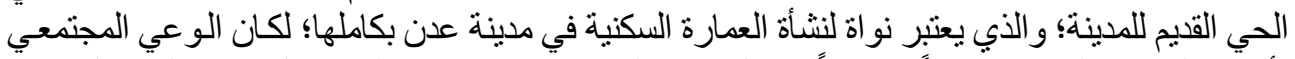

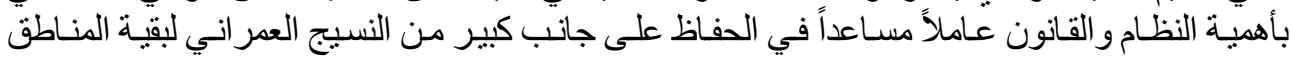

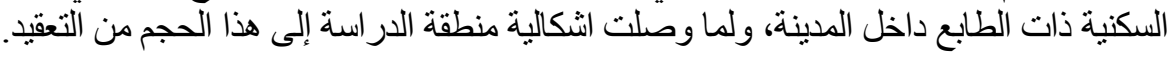

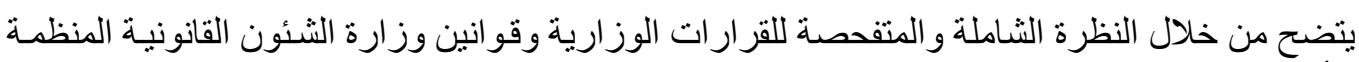

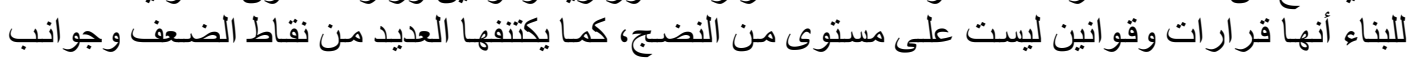

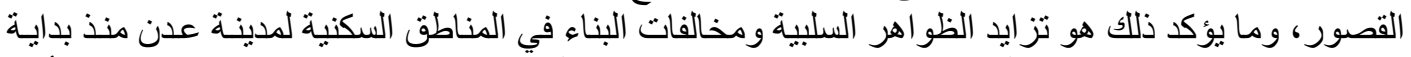

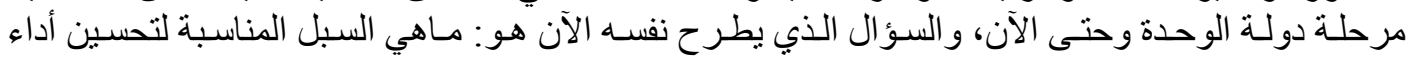

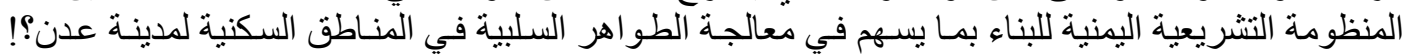

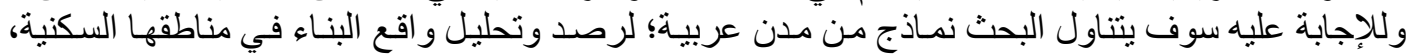

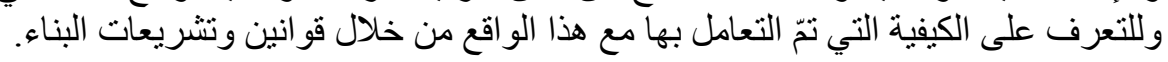

\section{4. واقع البناء في المناطق السكنية لنماذج من المدن العربية في ظل قوانين وتثريعات البناء}

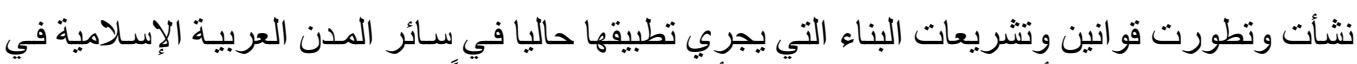

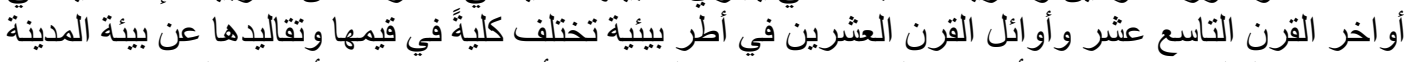

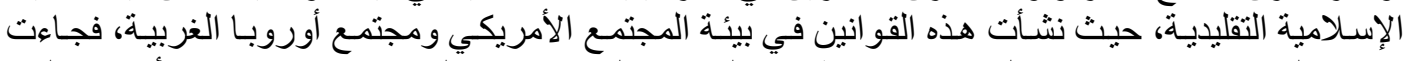

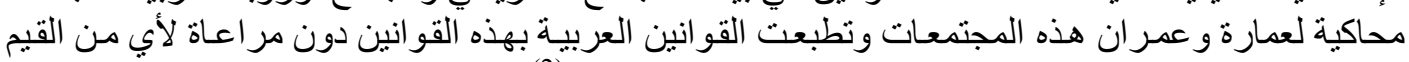

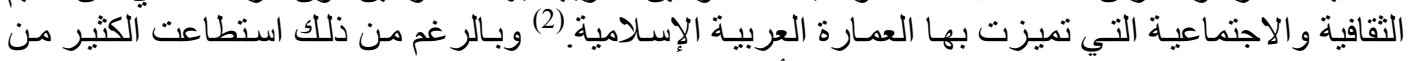

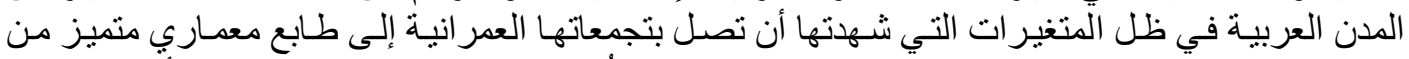

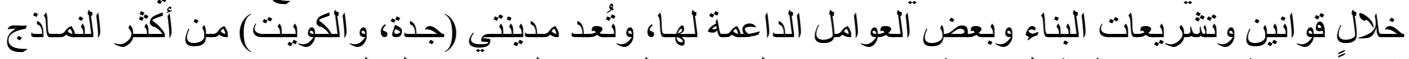

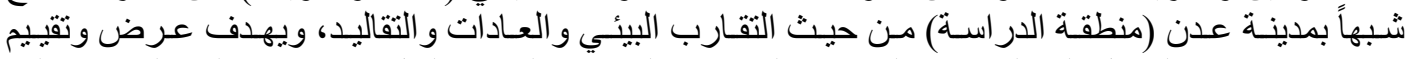

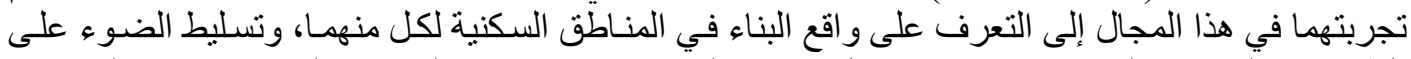

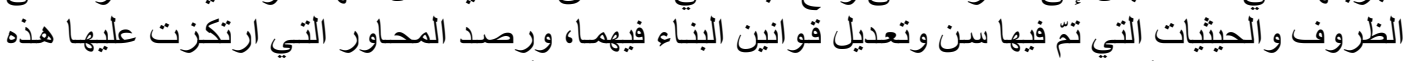

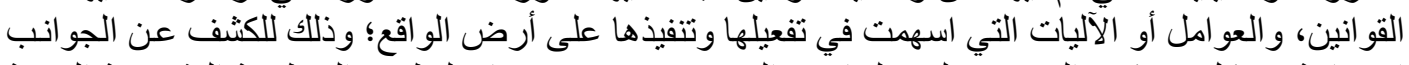

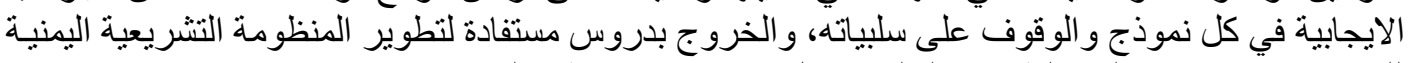

للبناء بما يسهم في معالجة الظو اهر السلبية داخل مدينة عدن (منطقة الدر اسة).

1.4 مدينة جدة

مرت النشريعات و الأنظمة البنائية في المملكة العربية السعودية بثلاث مر احل مختلفة:

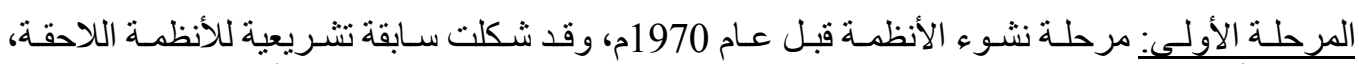

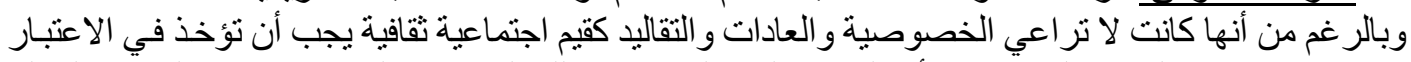

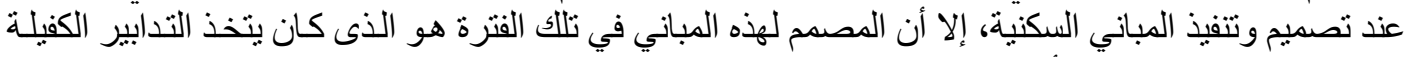

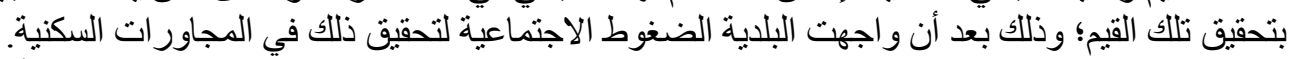

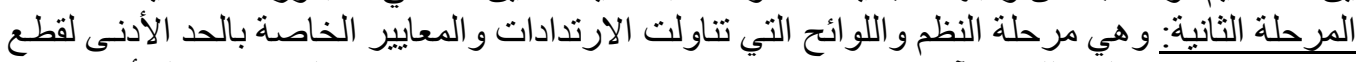

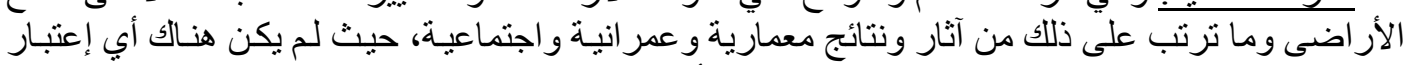

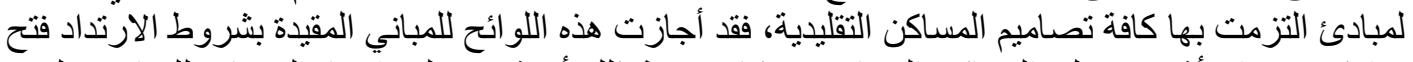

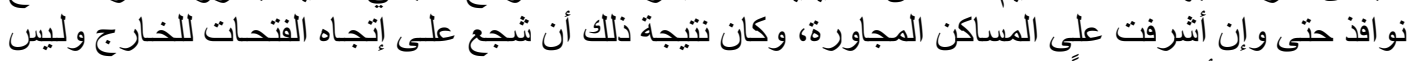

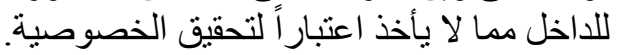


المرحلة الثالثة: و هي مرحلة مر اجعة النظم العمر انية السـابقة والتعديلات التي أُدخلت عليها وتركز فيها

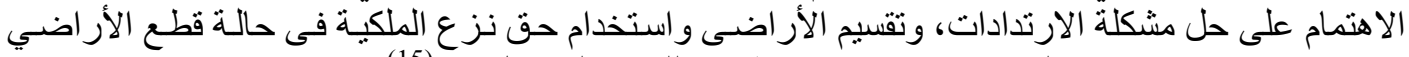

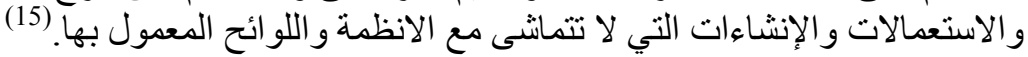

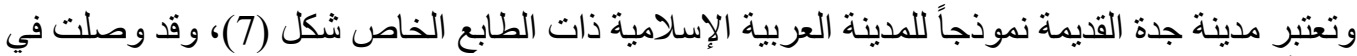

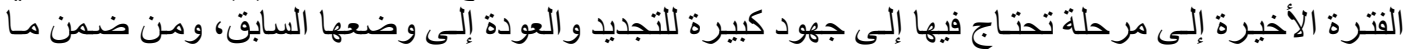

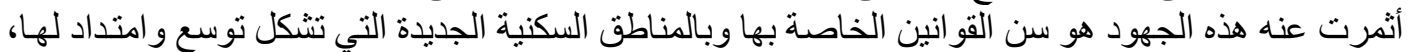

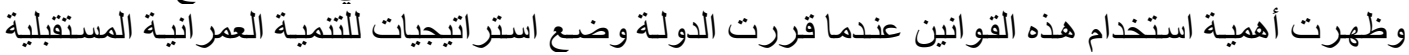

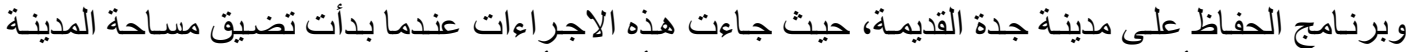

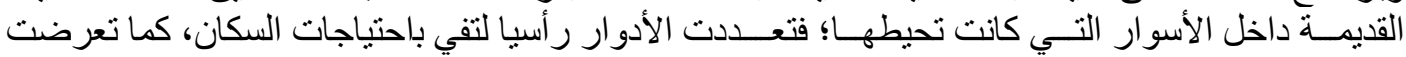

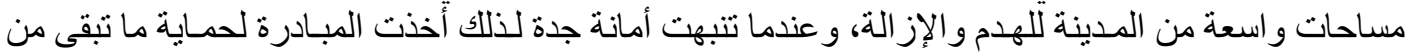

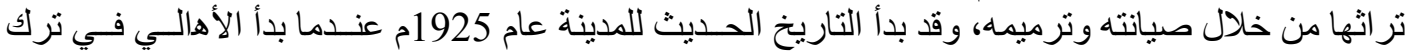

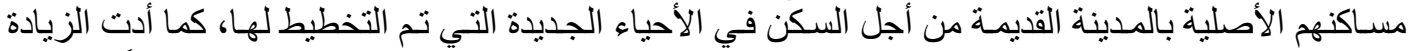

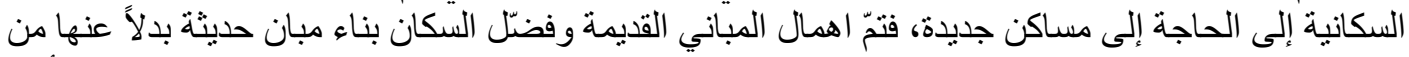

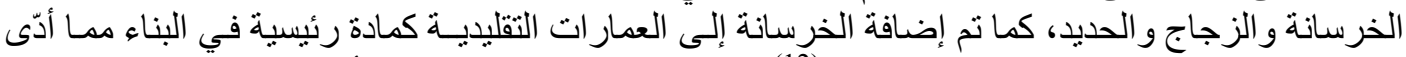

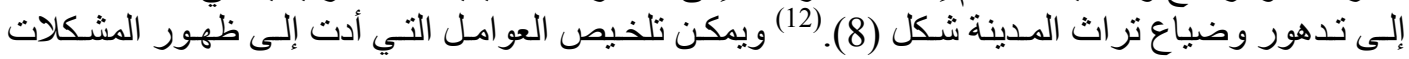
المعمارية و العمر انية في هذه المدينة المدينة كما يلي:

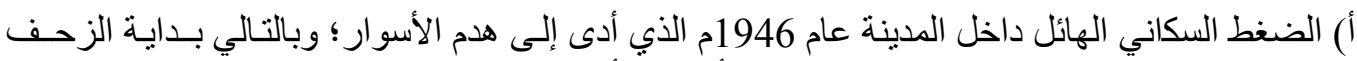

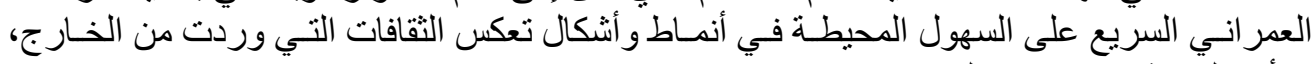
فبدأت المدينة تفقد وجهها الحضع عضى الحهاري.

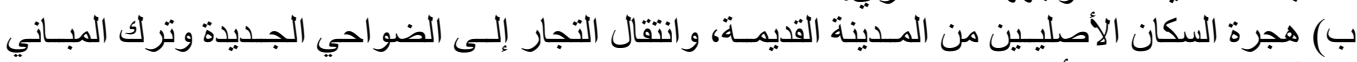

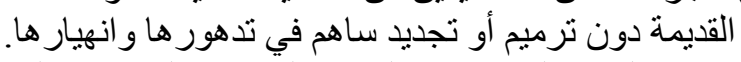

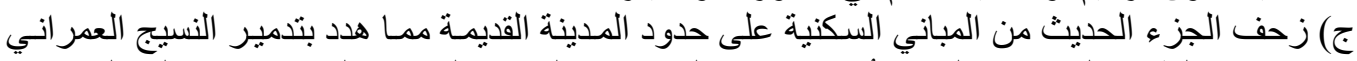

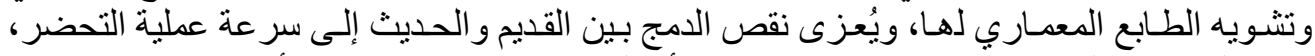

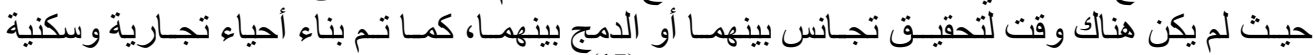

بأسلوب غربي على لفي الحدود الخارجية للمدينة القديمة.

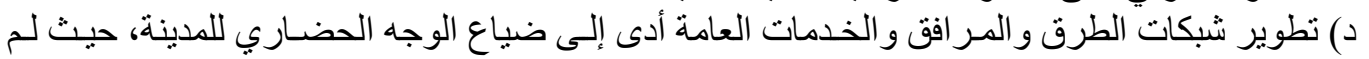

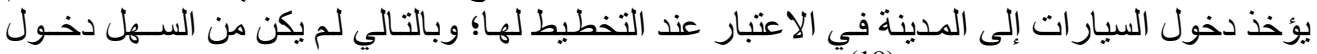

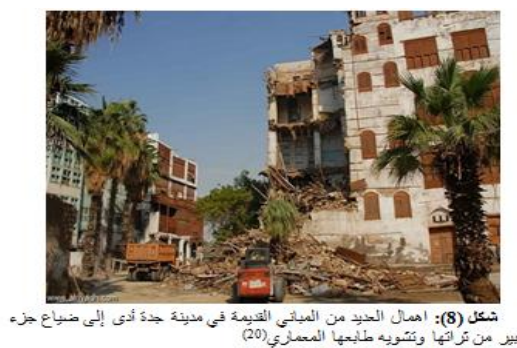
سيار ات الخدمة و الطو ارئ إليهار (18)

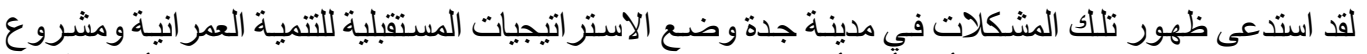

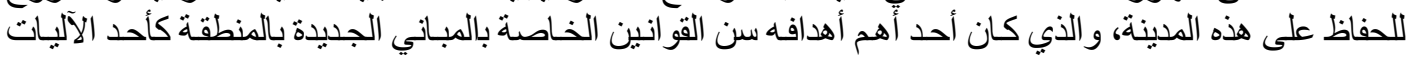

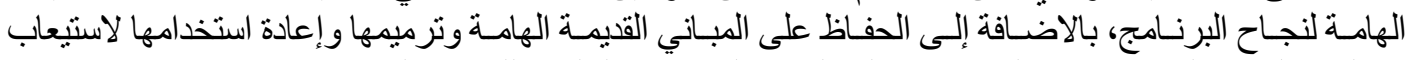

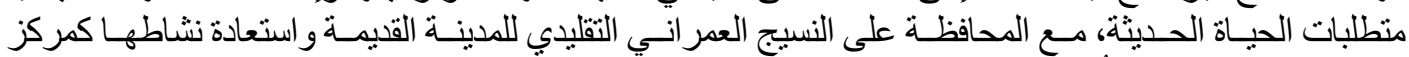

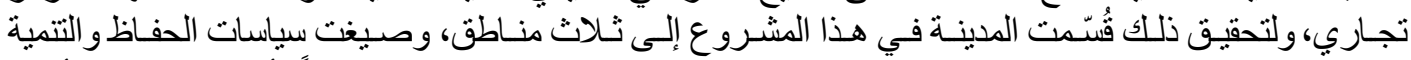

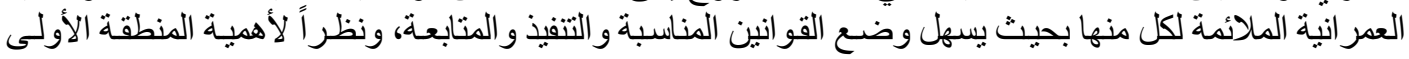


ابتسام عبداله ناصر عمبر - تحسين أداء المنظومة التشريعية للبناء في المناطق السكنية لمدينة عدن في ضوء.

من حيث كونها تمثنل الجزء التاريخي في المدينة (جدة القديمـة)؛ أرتأت أمانة جدة أن يسبق مرحلة سـن القوانين

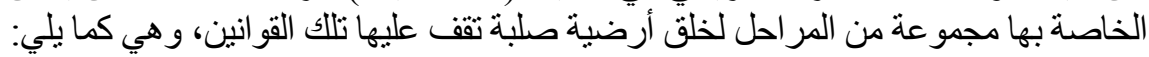

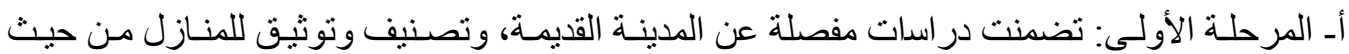

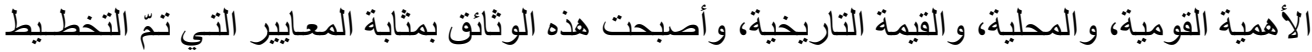
على أساسها لعمليات إعادة التأهيل.

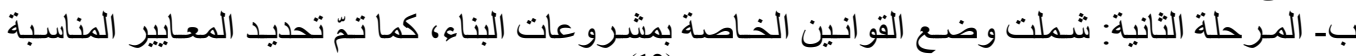

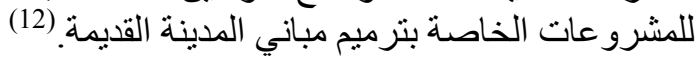

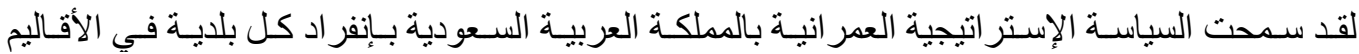

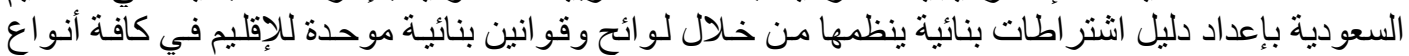

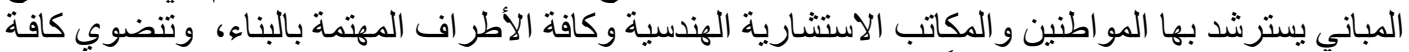

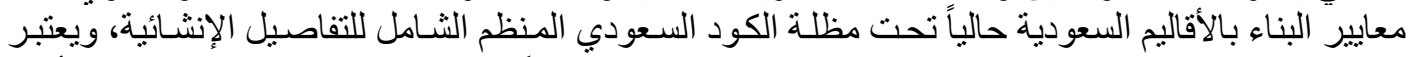

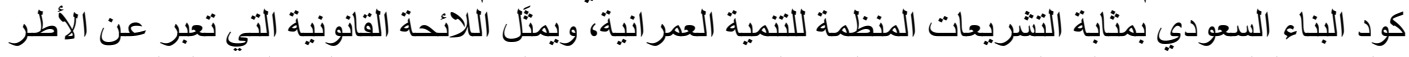
و الحدود الملزمة في عملية البناء، ويستند الكود السعودي (SBC) على مرجعية مجلس الكود العالمي (ICC)

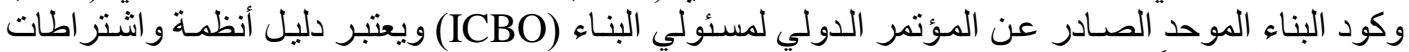

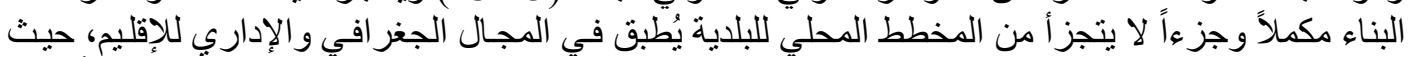

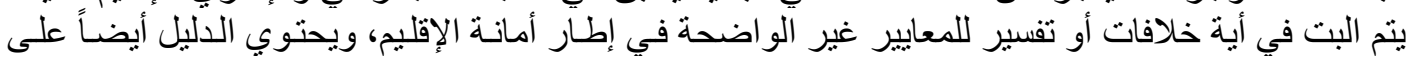

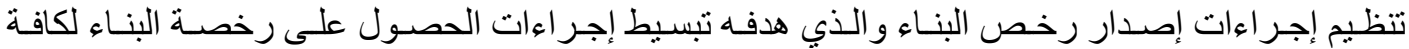

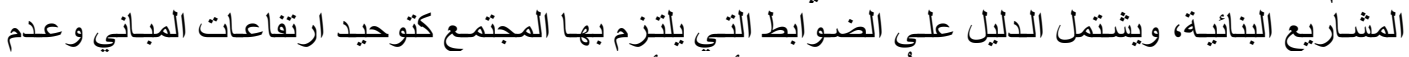

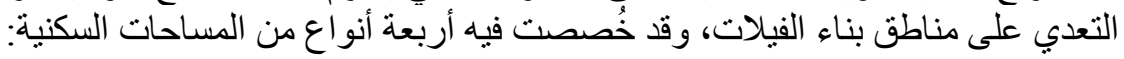

ـ مناطق الفيلات.

ـ مناطق الإسكان المعتمد وتحتوي على عمار ات أو فيلات مع مر اعاة الضو ابط التخطيطية.

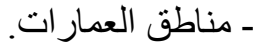

ـ المناطق العفوية وهي التي تُبنى بدون تخطيط مسبق (العشوائية).(9)

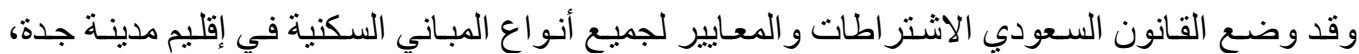

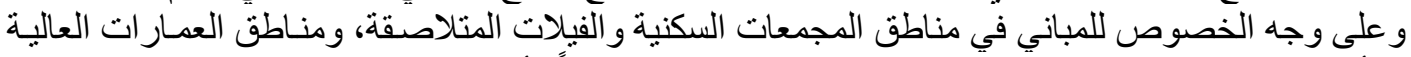

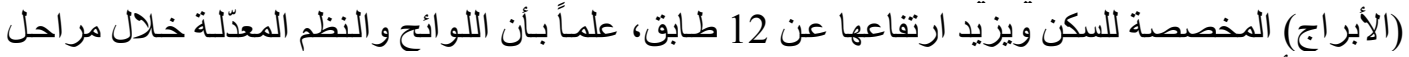

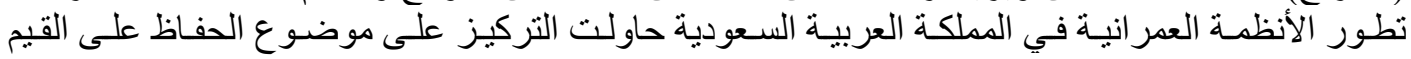

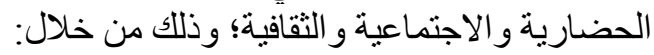

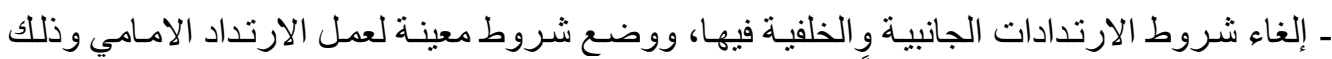

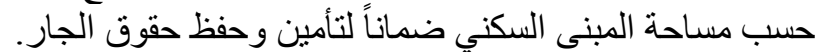

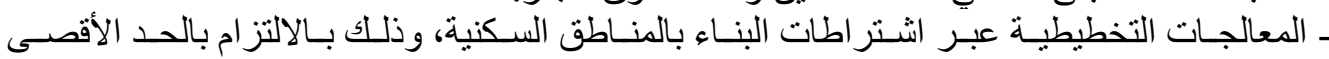

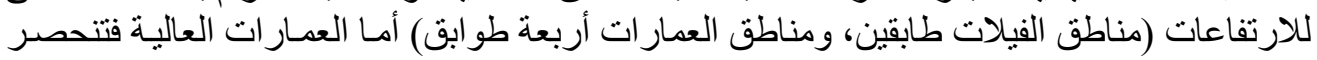
كما ركزت مناطق العمار ات السكنية التجارية.

- وضع معايير لمساحة مسطح البناء ووضع حد أدنى وحد أعلى لعدد الطو ابق تبعاً لهذه المساحة.

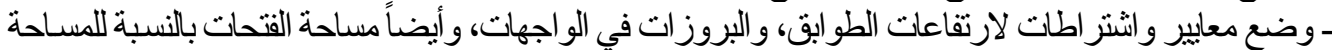

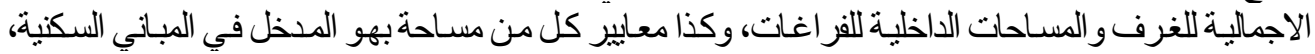

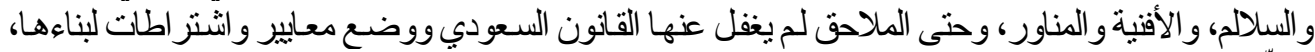

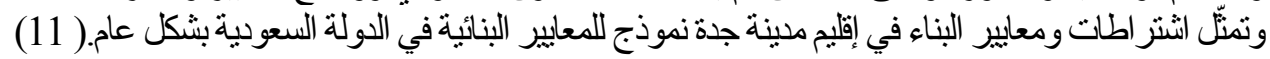

وتجدر الإشارة إلى أن هناك العديد من المعايير الأخرى التي لم يغفل عنها قانون البناء السعودي ارتبطت بـ: 
JES, Assiut University, Faculty of Engineering, Vol. 48, No. 1, January 2020, pp. 136-153

ـ الجانب التخطيطي و الأمني للمدينة مثل معايير : مو اقف السيار ات، وارتفاعات الأسوار حول الفيلات و العمار ات.

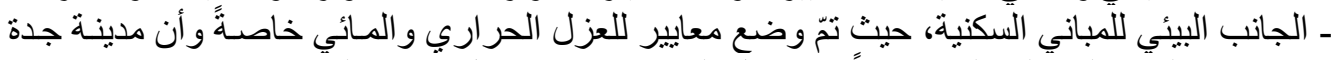

تعتبر من المدن الساحلية الحارة جداً في فصل الصيف وفئ كما هو حال منطقة الدراسة (مدينة عدن).

و ون وجهة نظر الباحثين فإن تخصيص الدليل لأربع أنواع من المسـاحات السكنية في المدينة ودمن بينها

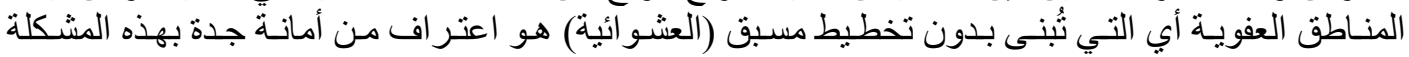

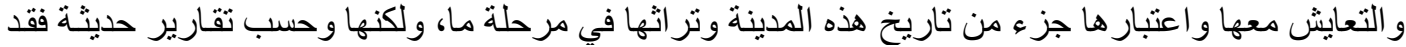

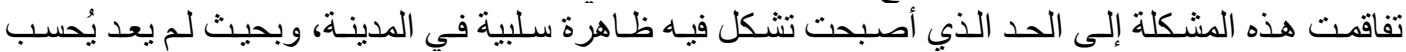

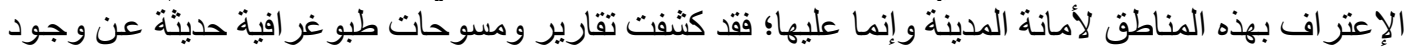

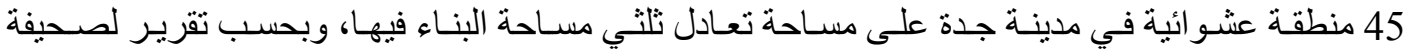

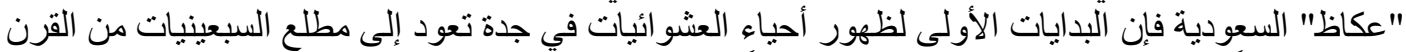

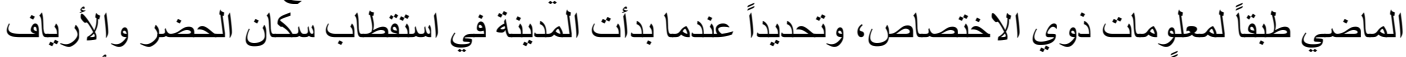

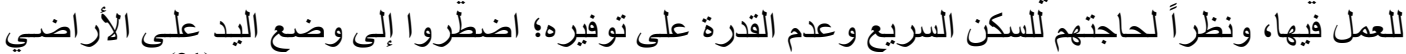

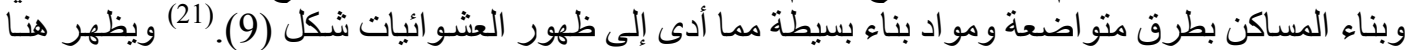
التأثير السلبي للعو امل الاجتماعية و الاقتصادية على التشكيل العمر اني والطابع المعماري للمدينة القديمة.

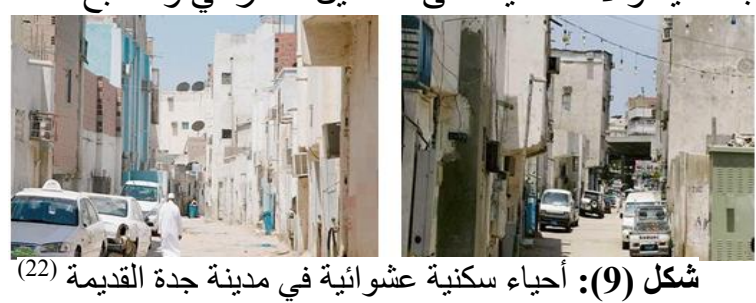

تقييم نموذج مدينة جدة: لعب العامل الاداري في هذا النموذج دوراً إيجابياً في التمهيد لنجاح دور العامل

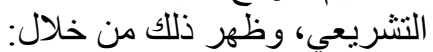

•وضع استر اتيجيات للتنمية العمر انية وبر امج للحفاظ على المدينة القديمة من التدهور الذي لحق بها وبمبانيها.

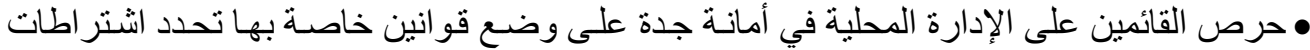

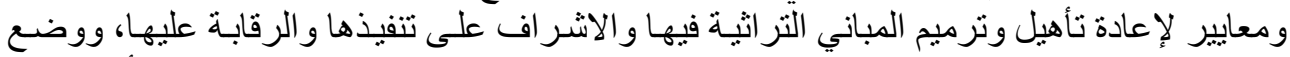

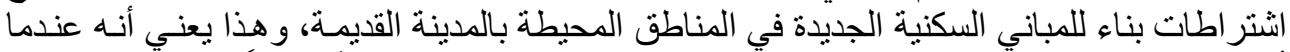

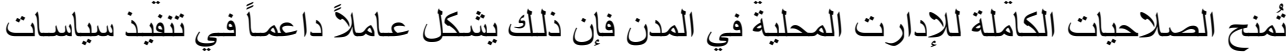

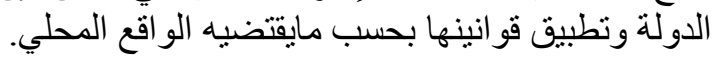

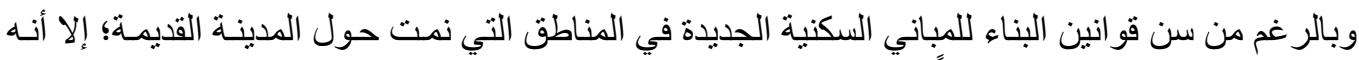

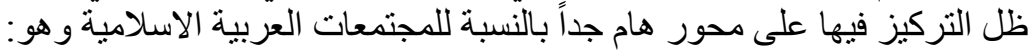

• الحفاظ على القيم الحضارية و الاجتماعية والثقافية (وفي مقدتها الخصوصية) وقد ظهرت أهمية هذا

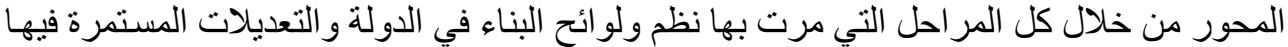

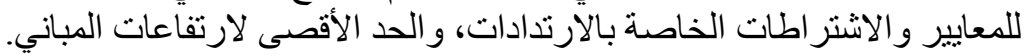

أما سلبيات هذا النموذج فتكمن في النقاط التالية:

ـ كان لتردي العو امل الاجتماعيةو الاقتصادية دوراً كييراً فيما آل إليهو اقع البناء في الأحياء السكنية لملينة جدة القيمة.

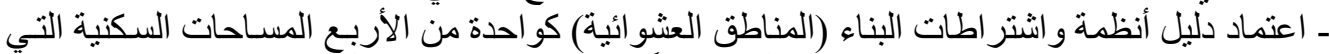

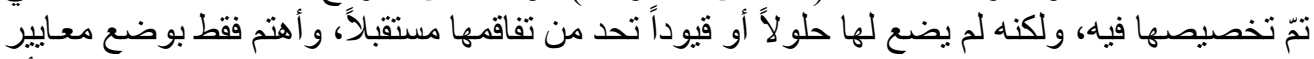

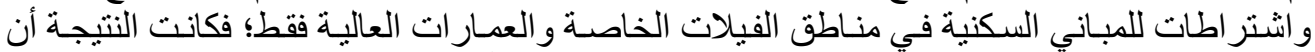

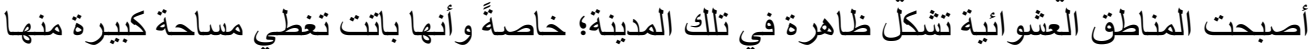

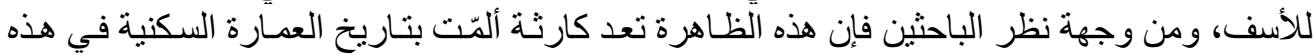


ابتسام عبدالهه ناصر عمبر - تحسين أداء المنظومة التثربعية للبناء في المناطق السكنبة لمدينة عدن في ضوء.

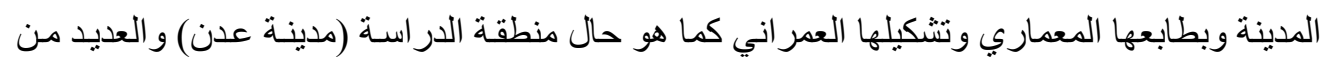

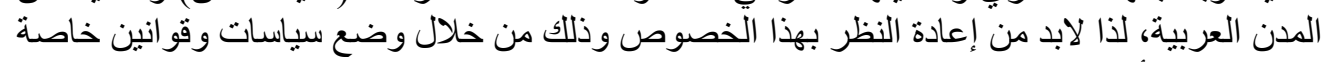

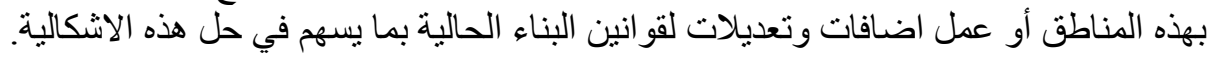
2.4 مدينة الكوبيت بهون

تنكل الييئة العمر انية للمسكن وبالذات المسكن الخاص في مدينة الكويت إثبكالية كبيرة للمتعاملين معها حيث أنها

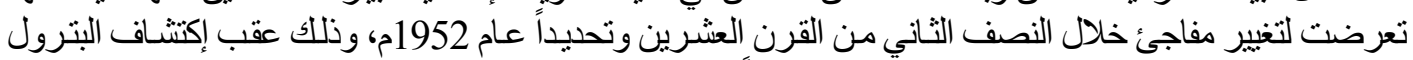

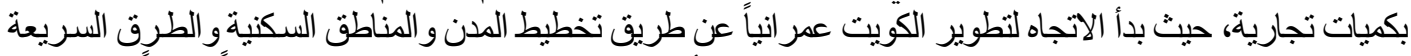

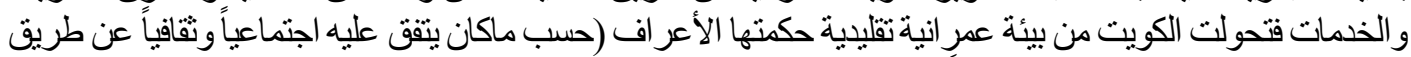

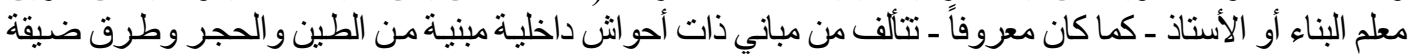

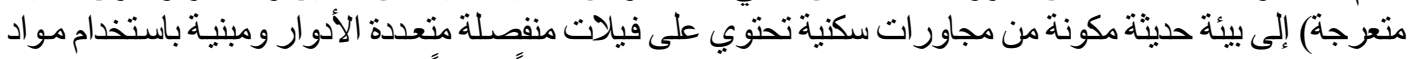

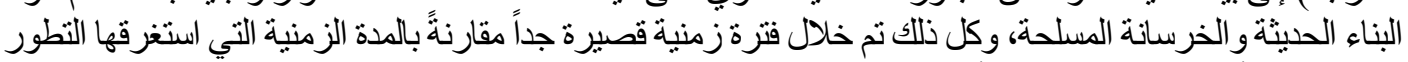

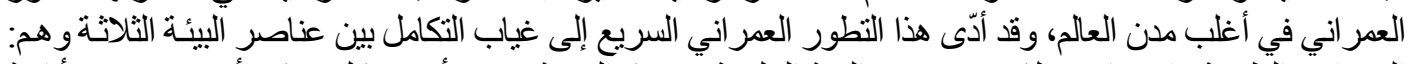

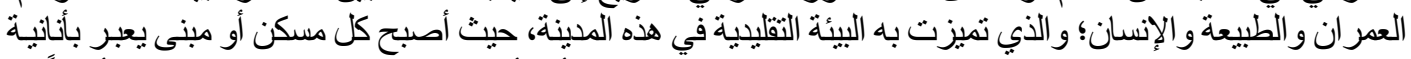

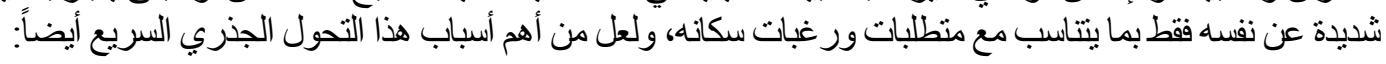

• تنبي قو انين البناء المعدول بها في دول أخرى دون مر اعاة لأهمية التحكم في التشكيل العمر اني للمناطق السكنية.

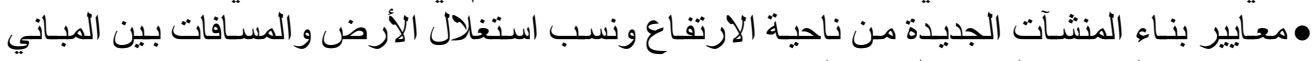
و عروض الثوارع التي تصنل بين المساكن.

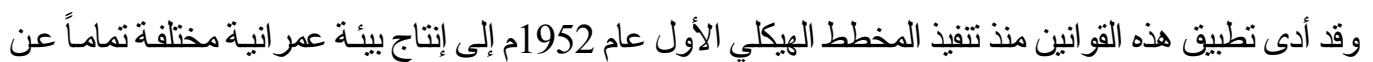

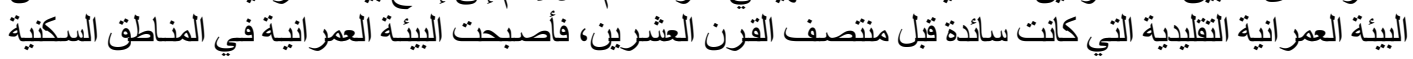

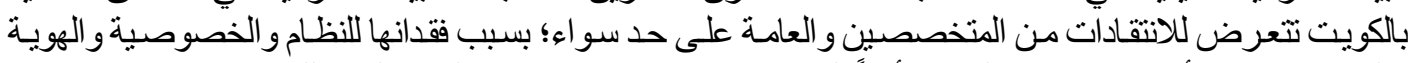

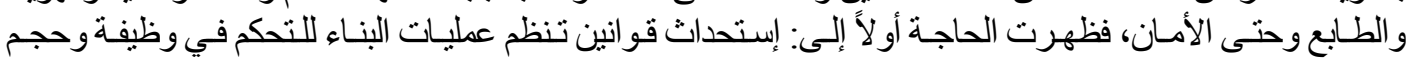
ومساحة و ارتفاع ومحتويات المبنى، ومرت هذه القو انين بمر احل مختلفة وتعليلات متعددة جاءت على على النحو التالي:

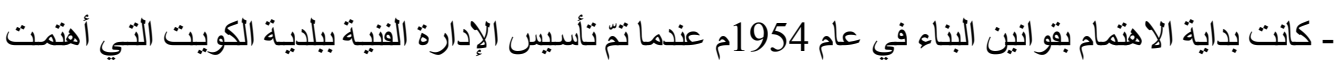

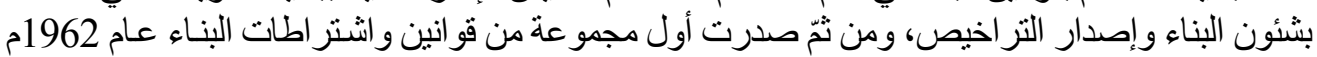

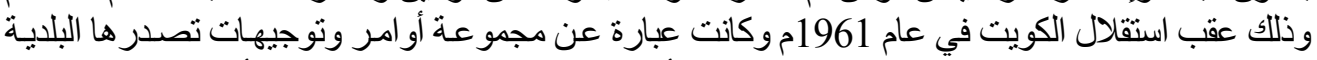

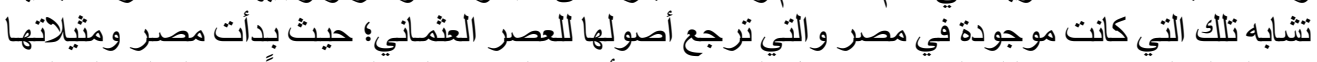

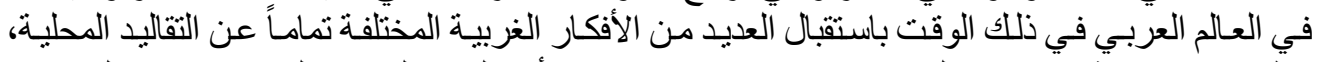

وظظهرت مجمو عة جديدة من القو انين في عام 1979م تضمنت أهم الهم المواد التي ماز الت سائدة حتى اليوم.

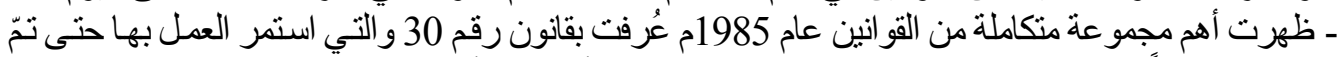

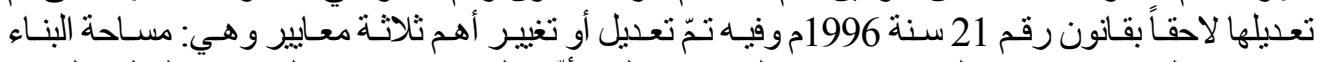

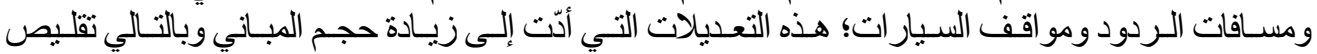

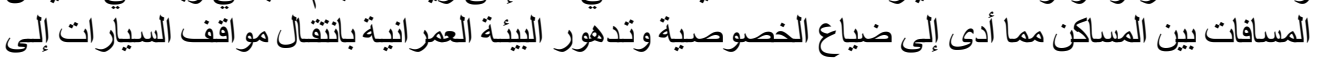

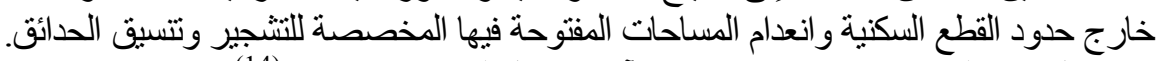

ـ ثمّ تعديل هذه القو انين عام 2000م وكان آخر تعديل لهام التهام عام 2002م. (14)

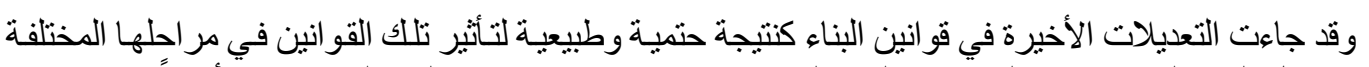

على تنكيل البيئة العمر انية في الكويت، و التي بالر غم من تعدد إيجابياتها؛ كانت لها سلبيات كبيرة أيضاً، حيث:

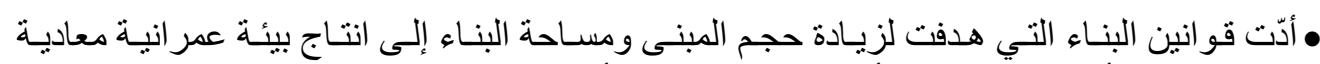

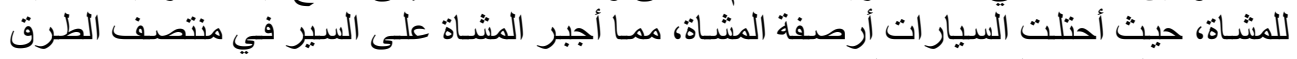

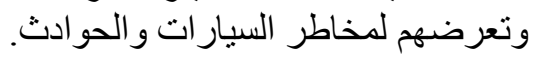


JES, Assiut University, Faculty of Engineering, Vol. 48, No. 1, January 2020, pp. 136-153

• أدى تقليص مسافات الردود بين المباني إلى مالا يزيد عن 3 أمتار إلى التعدي على حقوق الجـار كمـا يظهر

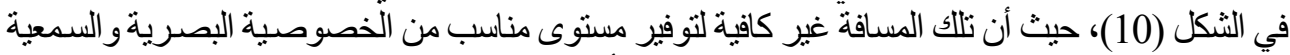

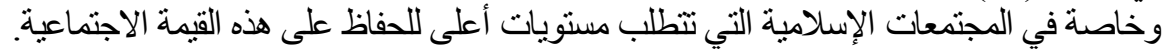

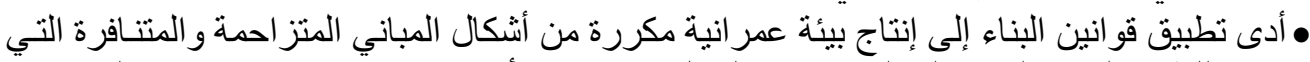

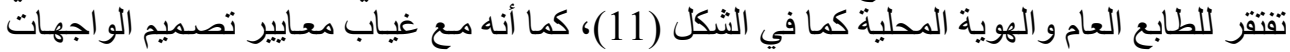

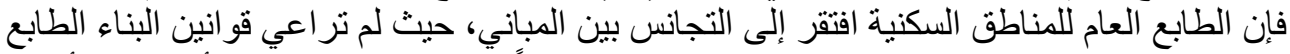

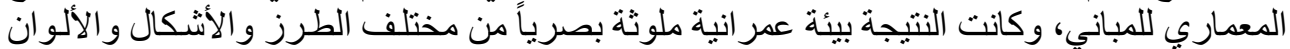

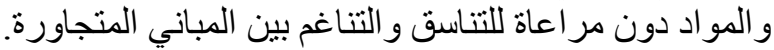

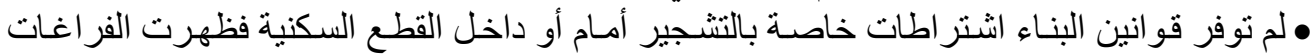

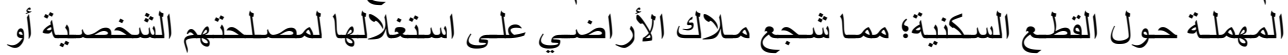
لتخزين القوارب و السيار ات. التهول.

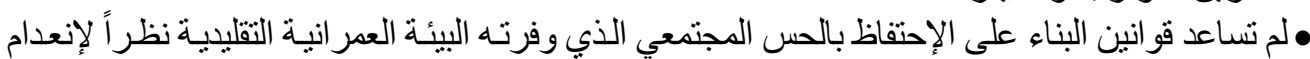

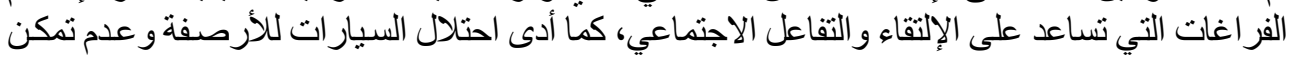

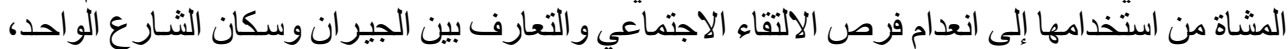

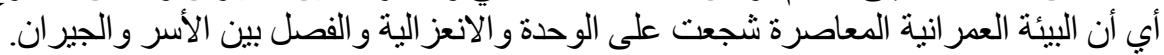

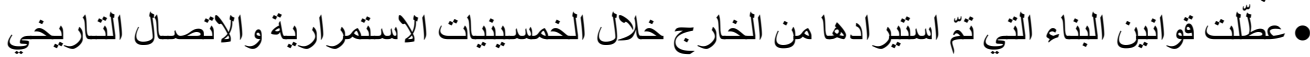

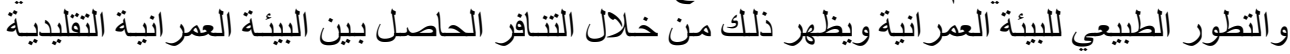

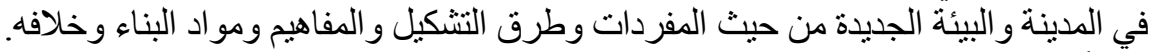

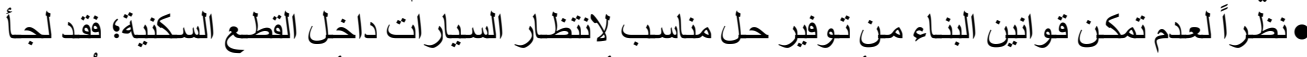

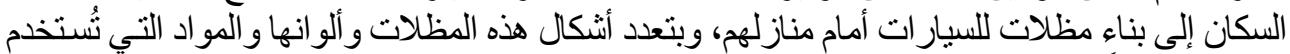

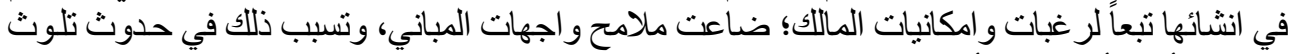

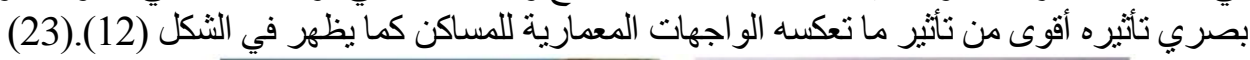
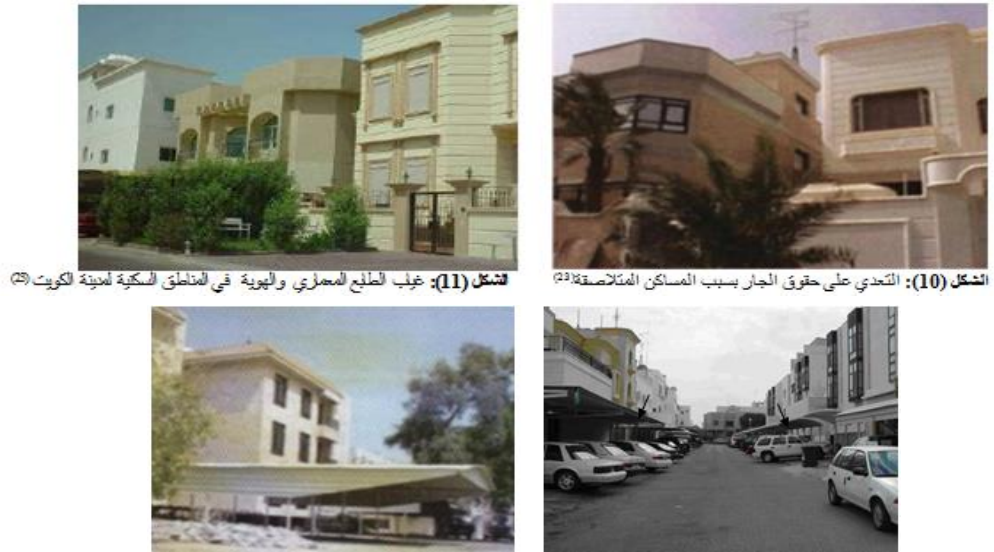

الثكل (12): تعدد أثكال مظلات السيار ات وألو انها يعتبر من أسباب ضياع ملامح الو اجهات و التلوث البصري(23) ونتيجة لكل ما سبق فقد كان من الضرورة أن تعيد بلدية الكويت النظر في قوانين البناء المعمول بها بشكل

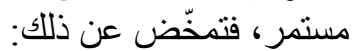

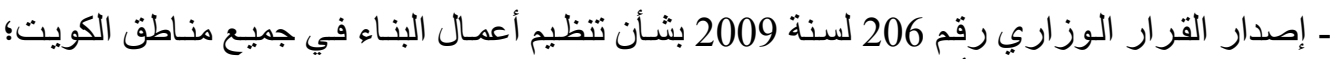

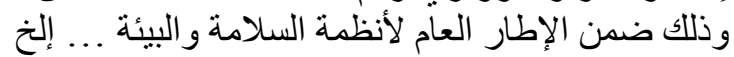

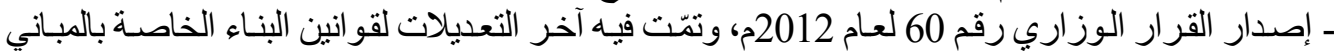

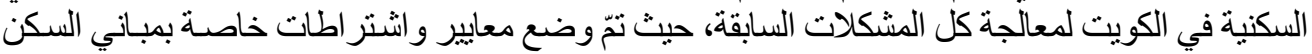

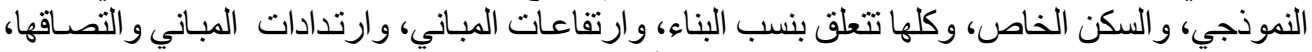

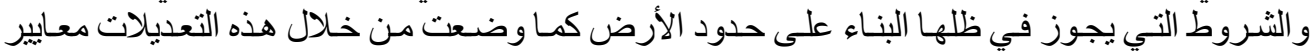


ابتسام عبداله ناصر عمبر - تحسين أداء المنظومة التشربعية للبناء في المناطق السكنبة لمدينة عدن في ضوء.

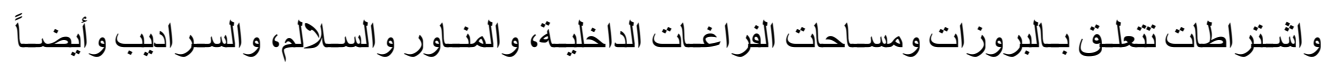

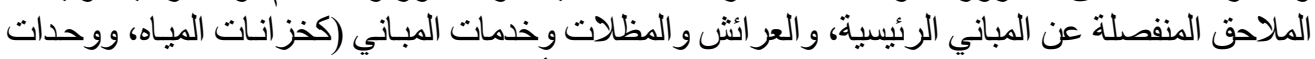

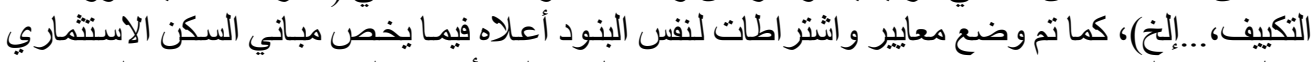

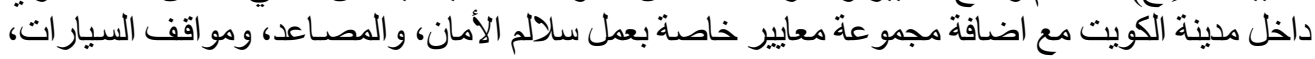

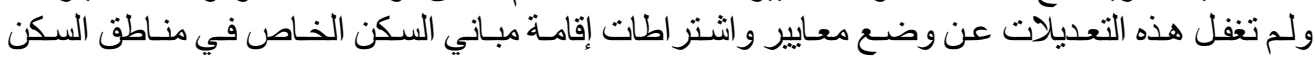

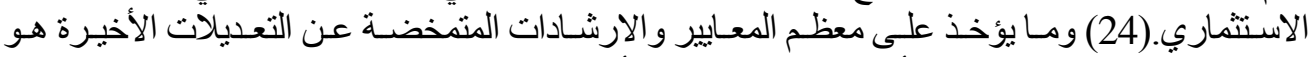

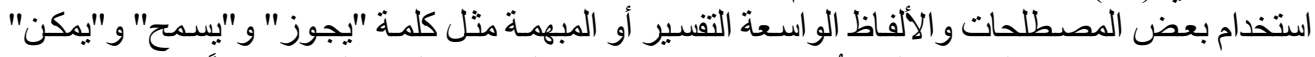

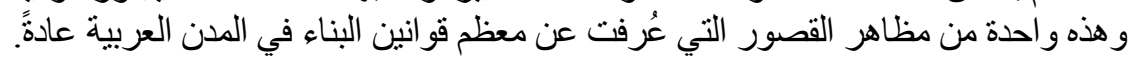

ونظر اً لتز ايد النهضة العمر انية في دولة الكويت بشكل مستمر ، فقد:

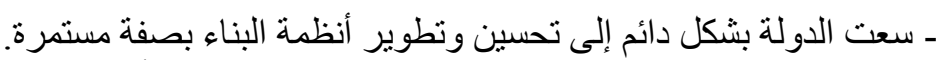

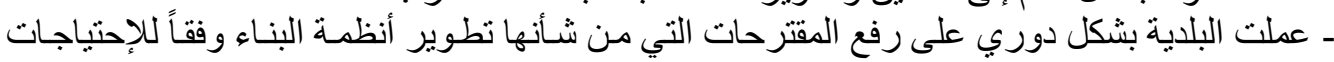

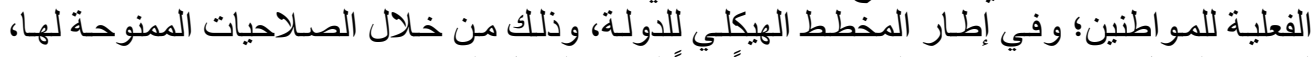

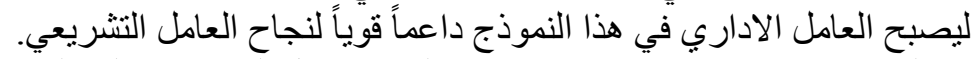

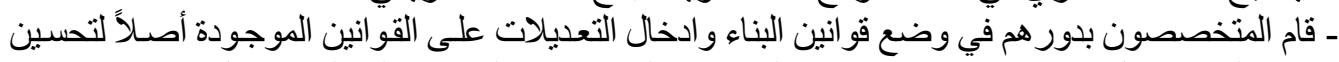

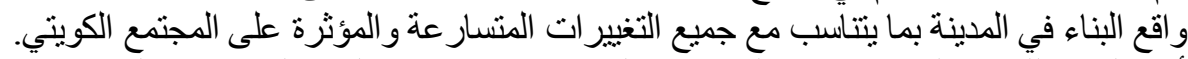

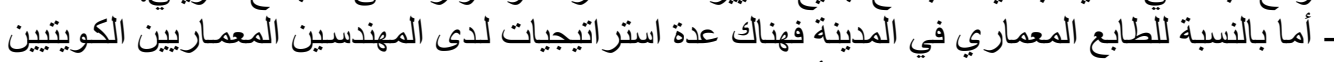

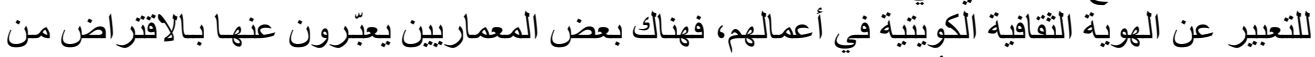

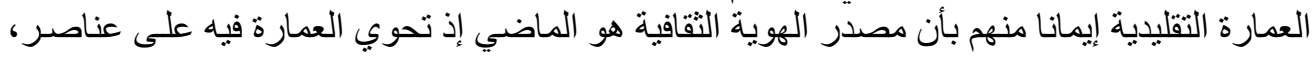

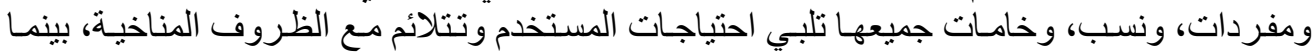

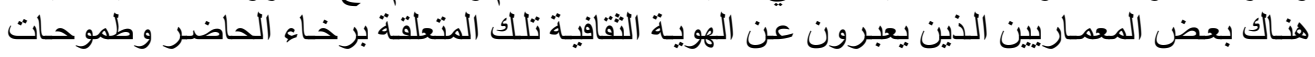

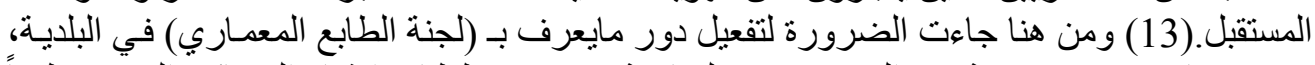

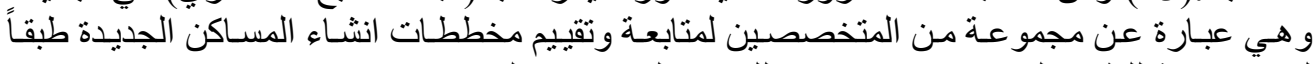

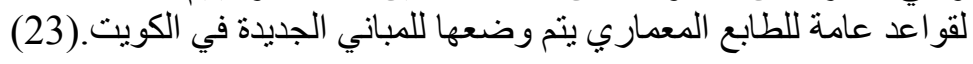
تقييم نموذج مدينة الكويت: يظهر هذا النموذج أيضاً الدور المحوري للعامل لاداري، وذللك من خلال بلدية

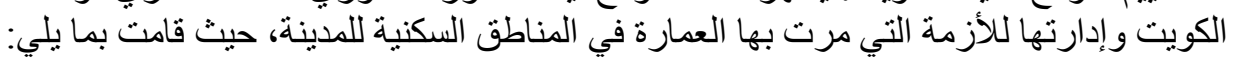

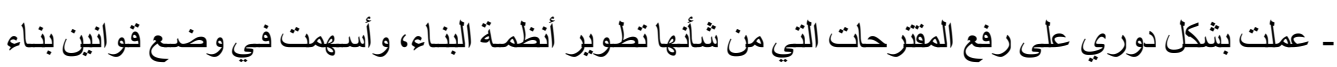

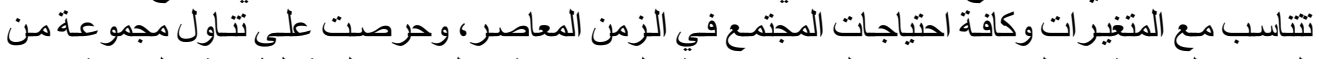

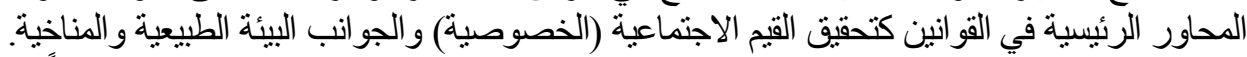

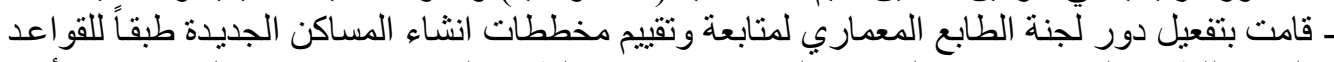

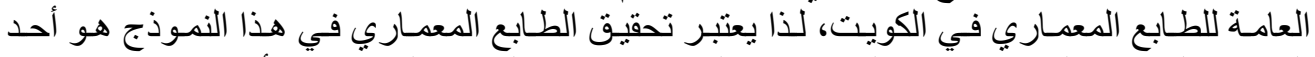

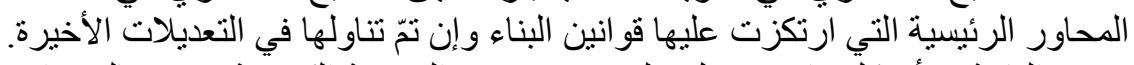

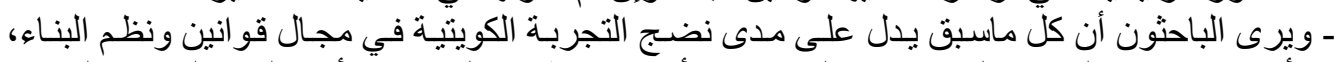

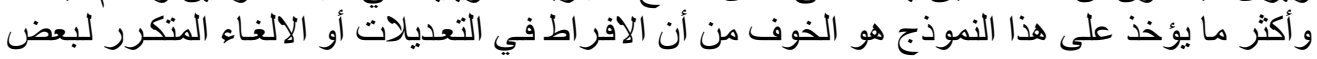

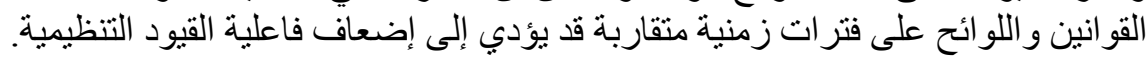

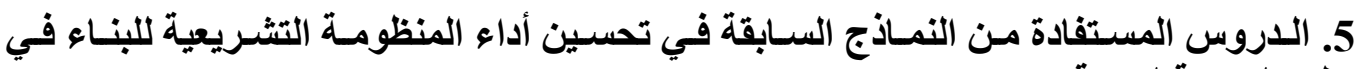
المناطق السكنية لمدينة عدن المسينفادة من

نخلص من خلال عرض النموذجين السابقين (جدة، و الكويت) أن الدور الايجابي لقوانين وتشريعات البناء

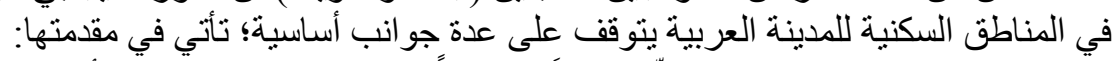

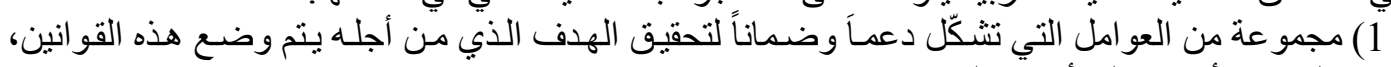

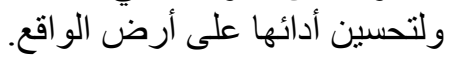


JES, Assiut University, Faculty of Engineering, Vol. 48, No. 1, January 2020, pp. 136-153

2) المحاور التي ترتكز عليها هذه القو انين، بحيث يمثّل بعضها ثوابت مشتركة وجو انب أساسية في عمارة المناطق

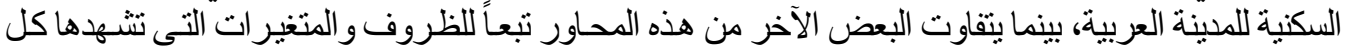

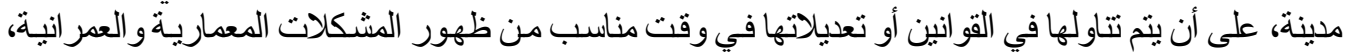

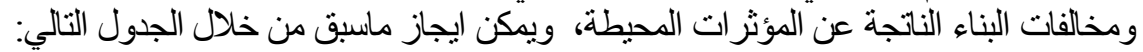
جلول (1) جو انب أساسية يتوقف عليها الدور الايجابي لقو انين وتشربعات البناء في المناطق السكنية للمدن العربية

\begin{tabular}{|c|c|c|c|}
\hline 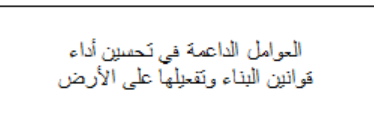 & 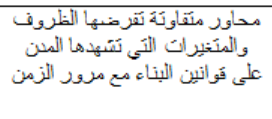 & 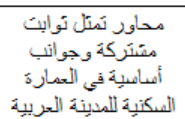 & نماذج المن \\
\hline 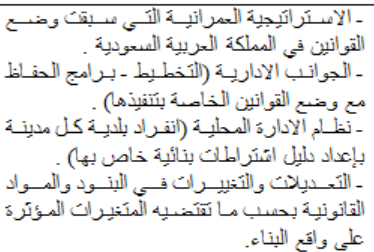 & 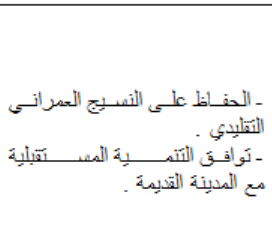 & \multirow{2}{*}{ 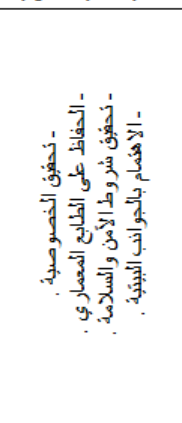 } & مدبلة جدةد \\
\hline 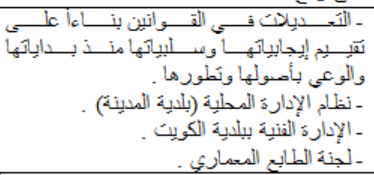 & 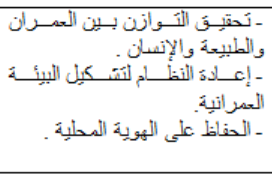 & & 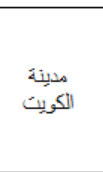 \\
\hline
\end{tabular}

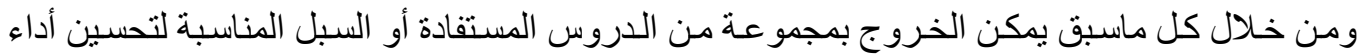
المنظومة اليمنية لقوانين وتشريعات البناء في المناطق السكنية لمدينة عدن، وهي على على النحو النالي:

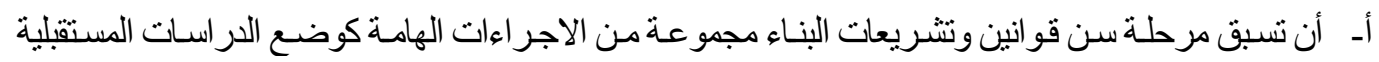

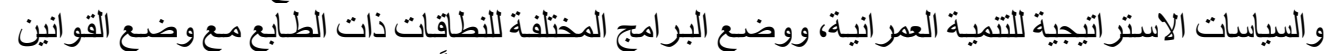

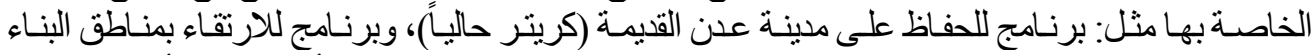

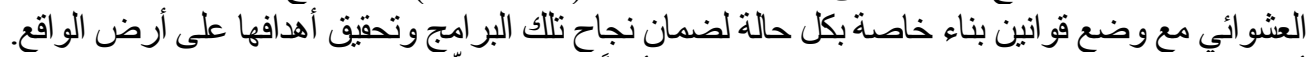

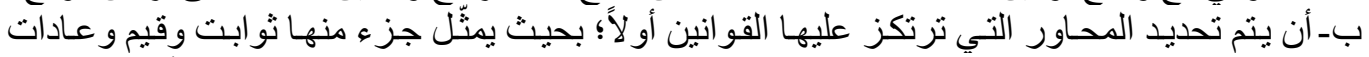

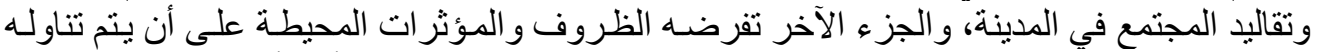

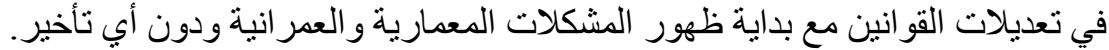

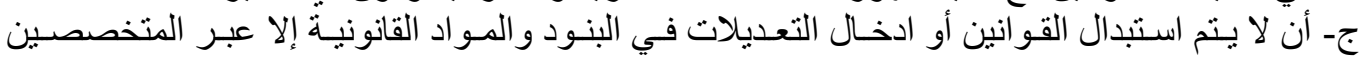

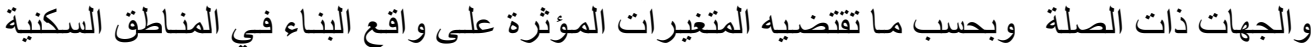

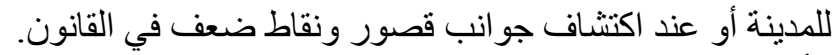

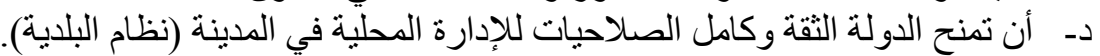

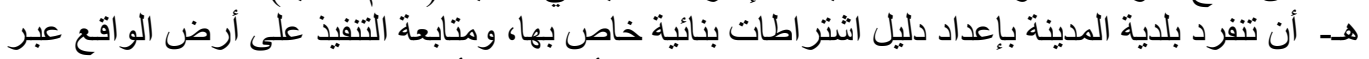

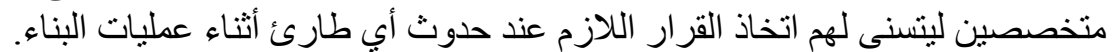

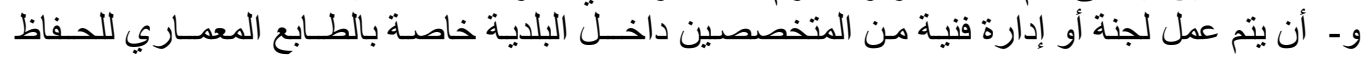
على الهوية المحلية للمدينة وبعدها الثقافي و التاريخي وخاصة في التي حيها القديم (عدن القديمة).

6. النتـائسج والتوصيات

$$
\text { 1.6 النتـائسج }
$$

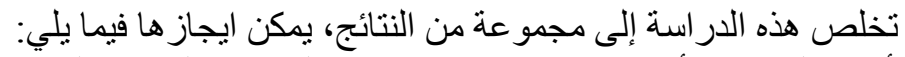

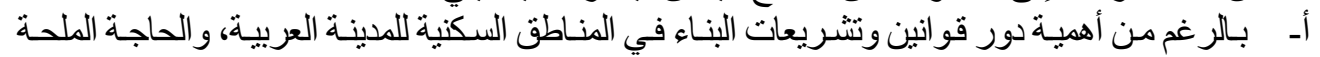

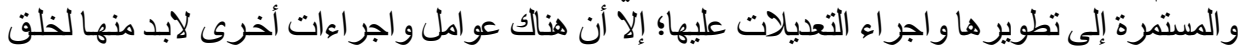

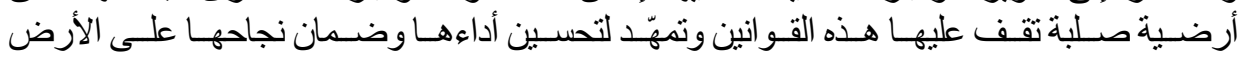


ابتسام عبداله ناصر عمبر - تحسين أداء المنظومة التشربعية للبناء في المناطق السكنبة لمدينة عدن في ضوء.

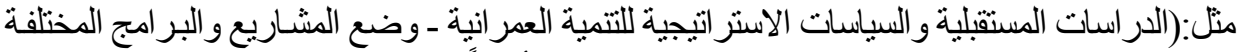

لبعض المناطق التي بحاجة لها مع وضع قو انين خاصة بها أيضاً ـ تفعيل نور السلطات البهات المحلية).

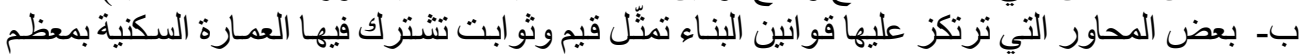

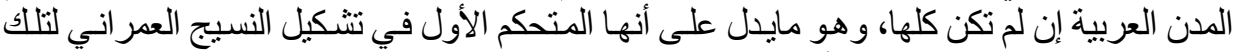

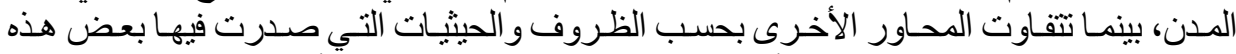

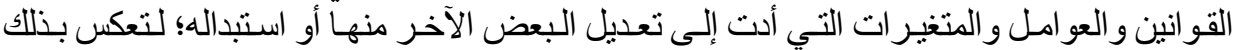

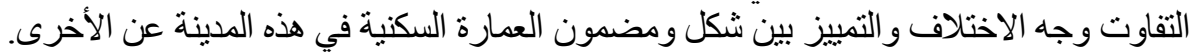

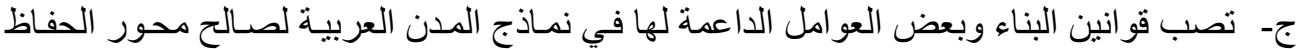

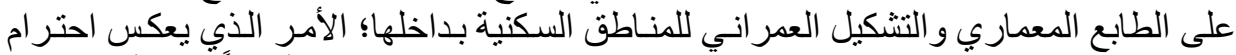

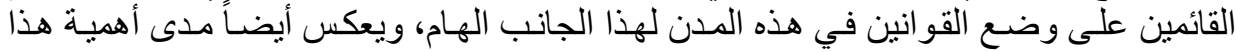

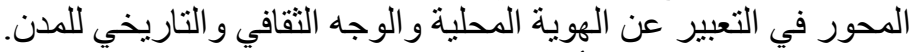

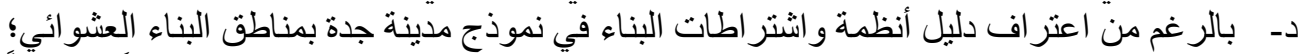

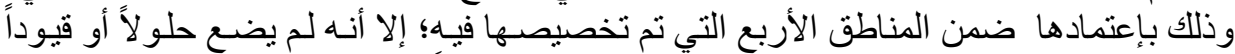

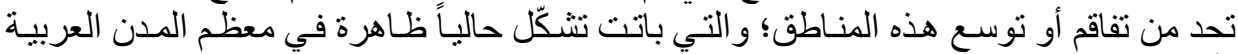

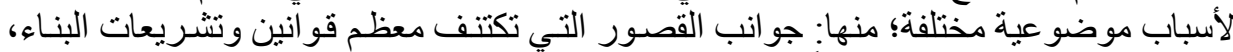

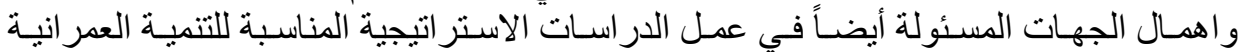

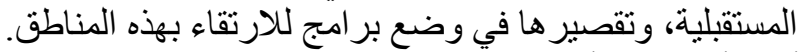

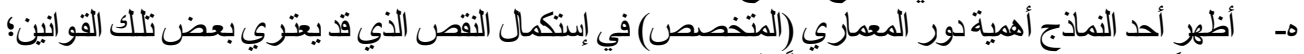

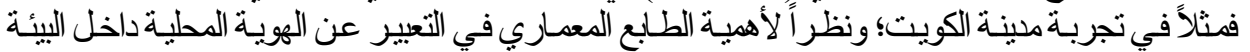
العمر انية الجليدة؛ فقد تم تتكيل لجان بحيث يكون المعماري (المتخصص) على رلئ رأسها لمتنابعة هذا الجانب.

$$
\text { 2.6 }
$$

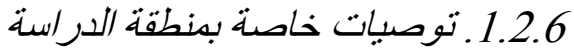
يوصي البحث في ضو غء النتائج السابقة بما بلئي:

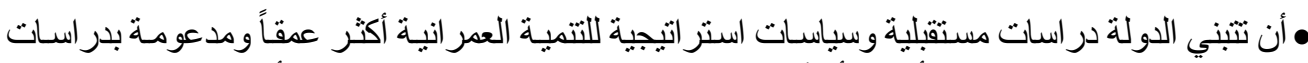
تخطيطية وتقصيلية للمدن و الأقاليم، أو يُعاد النظر في السياسات السابقة قبل اجر اء أبي تعديل في القو انين.

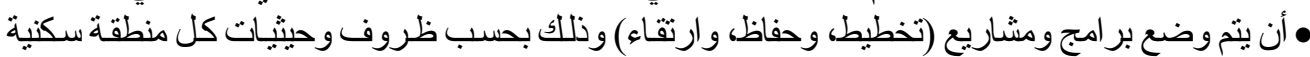

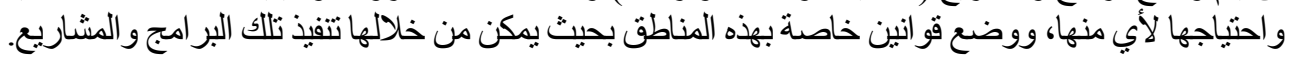

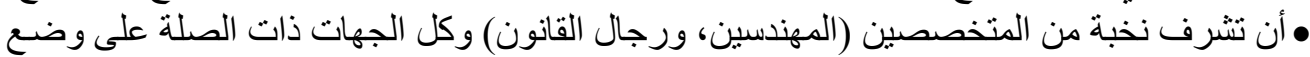

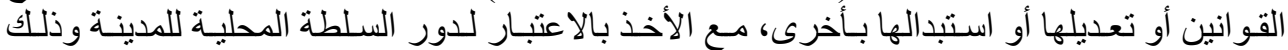

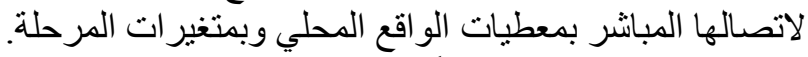

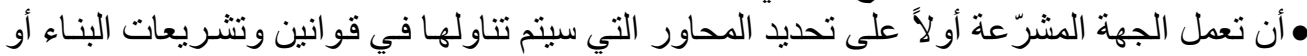

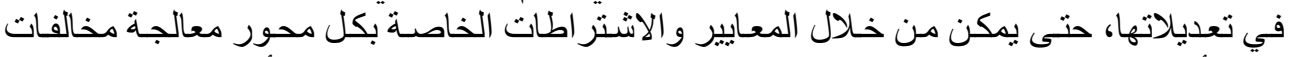

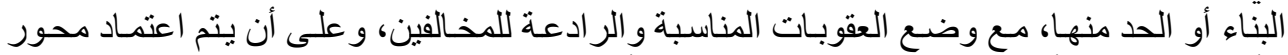

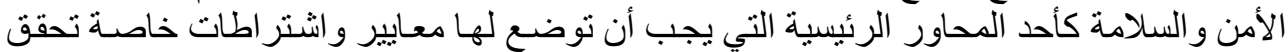

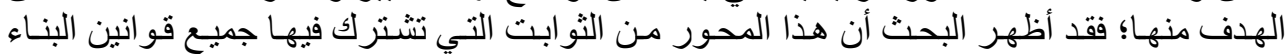

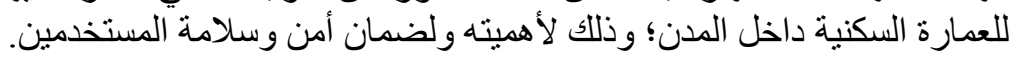

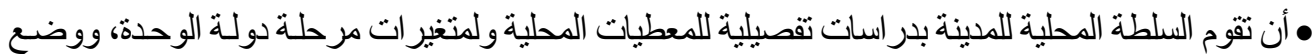

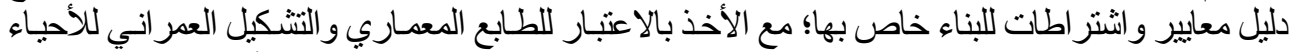

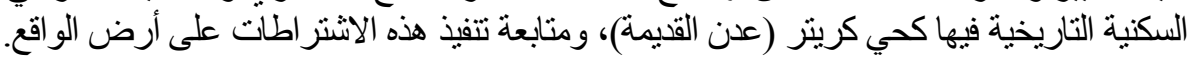


JES, Assiut University, Faculty of Engineering, Vol. 48, No. 1, January 2020, pp. 136-153

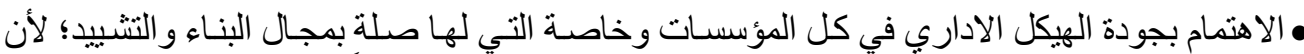

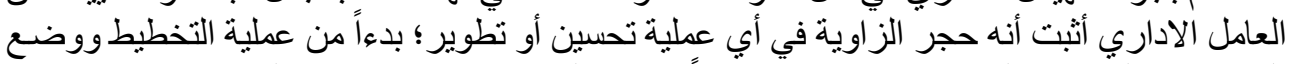

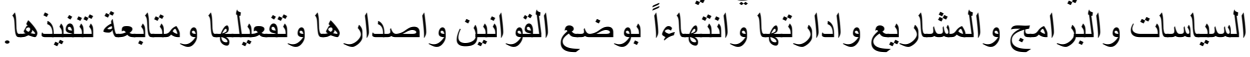

2.2.6 توصبات عامة

كما توصي الدراسة بمجمو عة من التوصيات العامة، و هي على النحو التالي:

• أن يتم اصدار القو انين وتعديلها وتفعيلها في الوقت المناسب لظهور المشكلات المعماريـة والعمر انية

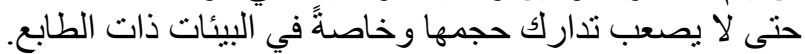

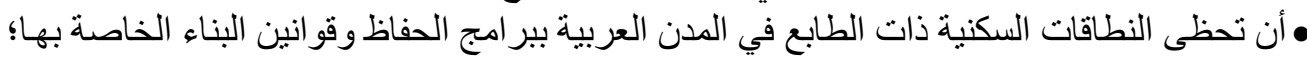

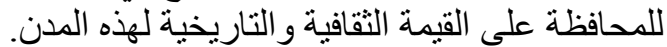

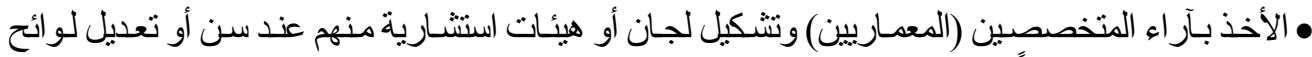

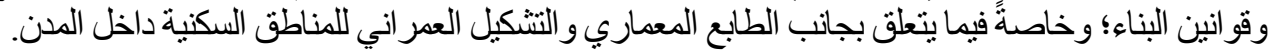

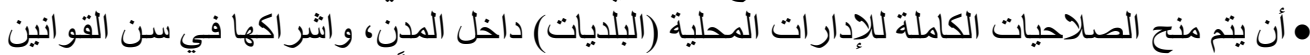

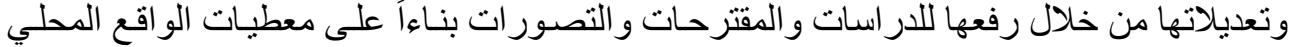

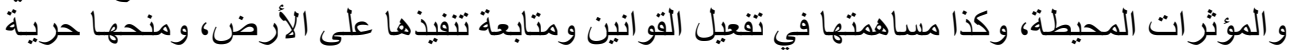

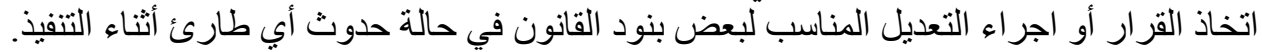

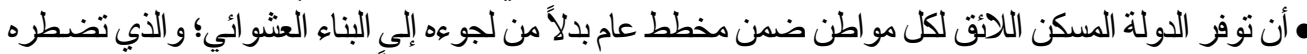

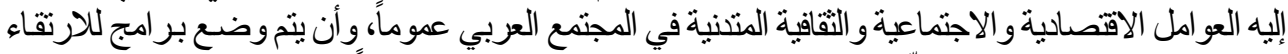

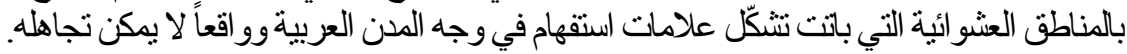

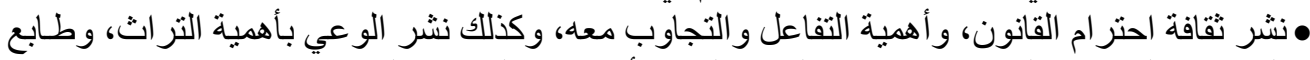
المكان، و الهوية، و القيم الاجتماعية والثقافية آهمية لأفى الأفر اد في المجتمع العربي.

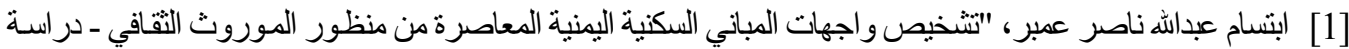

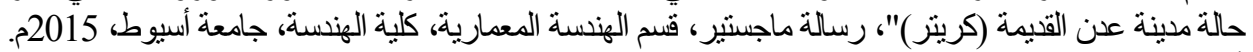

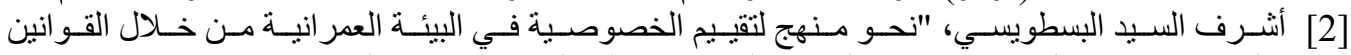

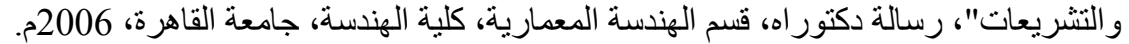

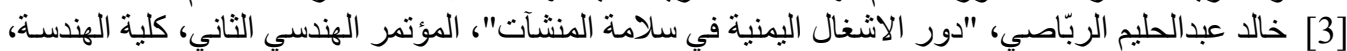

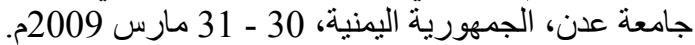

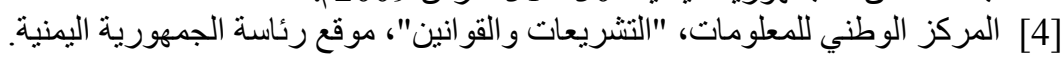

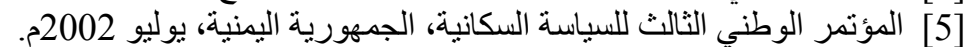

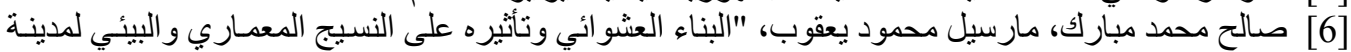

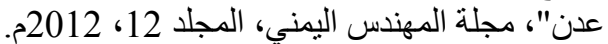

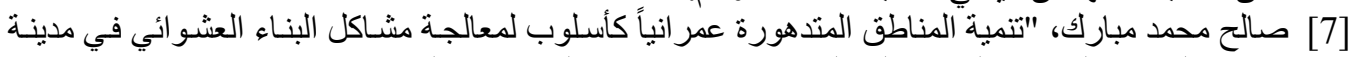

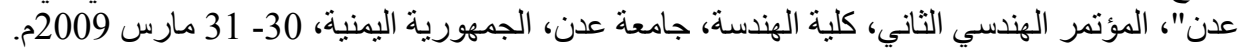

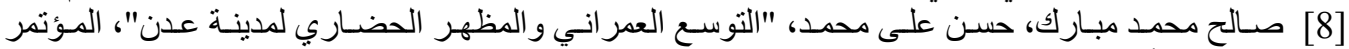

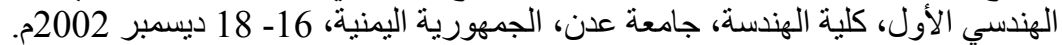

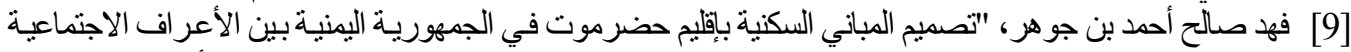

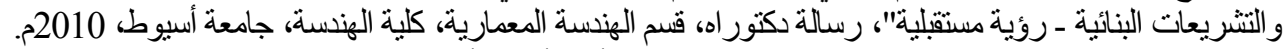

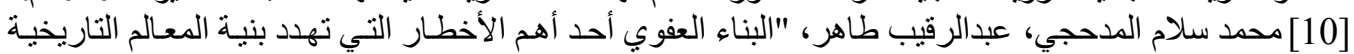

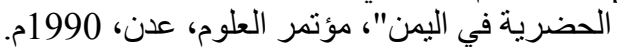
[11] من القانون السعودي اليدي.

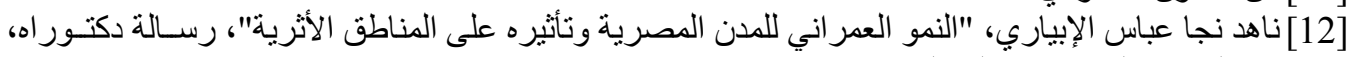

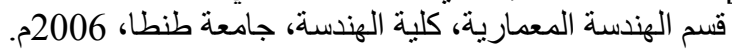


ابتسام عبداله ناصر عمبر - تحسين أداء المنظومة التشريعية للبناء في المناطق السكنبة لمدينة عدن في ضوء.................

[13] و لاء عزت محمد حسـين، "تأثير قو انين البنـاء على الهويـة المعماريـة تطبيقـا على المجتمعـات العمر انيـة

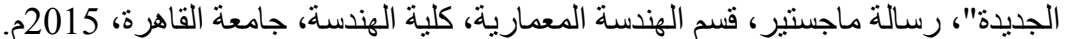

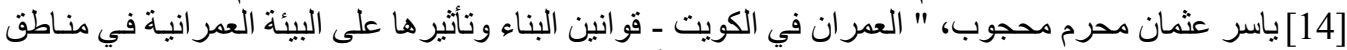

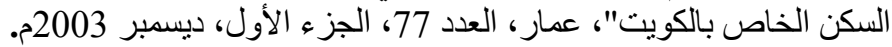

[15] Blanco, S, "URBAN FORM IN ARAB WORLD", Thames and Hadson Press, London, 2000.

[16] https://www.alayyam.info/Uploads/Content/0902/3O4SUTC0-GJ4SC8/Enma.jpg.

[17] Bokhari, Abdulla Y., Conservation in the historic district of Jeddah.

[18] Eunice, M.Lin, Conservation of the oldown of Jeddah .

[19] https://www.okaz.com.sa/new/Issues/20101221/Images/b70.jpg.

[20] http://www.alriyadh.com/media/thumb/2a/6a/1000_6001dda101.jpg.

[21] https://www.alarabiya.net/articles/2012/03/31/204333.html.

[22] https://www.maaal.com/sites/default/files/wpcontent/uploads/2014/04/10259_image_0_0.jpg.

[23] https://issuu.com/ymahgoub/docs/ymbuildingregulations.

[24] www1.baladia.gov.kw/main-web/buldlw/table1/01.htm.موقع بلدية الكويت.

\title{
IMPROVING THE PERFORMANCE OF BUILDING LAWS IN THE RESIDENTIAL AREAS OF ADEN CITY IN THE LIGHT OF THE POSITIVE ROLE OF BUILDING LAWS IN ARAB CITIES
}

\begin{abstract}
For three decades (since 1990 to date), residential areas in Aden City in the south of Yemen have been suffering from the spread of squatter and imported architectural patterns and building violations. During that period the city has witnessed several changes which have their great effects on the situation of building in residential areas. Several building decisions and laws have also been made. Some of these decisions and laws have been defective and deficient, and some could not be implemented. This research paper is intended to explore the suitable ways that can contribute to improving the performance of Yemeni building laws in the residential areas of Aden City in the light of the positive role of building laws in some Arab cities which could help their urban communities reach a distinguished architectural character in the light of the changes witnessed by their communities. The researchers have concluded some of the ways through which the objective of this study can be attained. Perhaps the most important of these ways are the following:
\end{abstract}

-The building law making stage should be preceded by a set of important measures and procedures such as the development of future studies and strategic policies of urban development, and the development of different programs for characterized and squatter areas (e.g. preservation - promotion) and making laws for them.

- Specifying the axes on which laws rest so that some of them form constants and values that characterize residential buildings in Arab cities in general, and some may vary depending on the changes taking place in each of these cities, and incorporating them into law amendments.

- The State should have trust in the municipality and give it full authority so that it can prepare its own building provisions manual and monitor the enforcement of laws on the ground by specialists who can take the necessary decision when an emergency occurs during the building operations.

- Activating and enhancing the role of specialists through their participation in making laws and their amendments, and forming technical committees and administrations involving them within the municipality to preserve the architectural character and local identity of the city and its cultural and historical dimension, especially in its old district (Old Aden).

\section{The present research paper deals with the following points:}

1. Introduction: Problem, objective, methodology and scope of the study.

2. The situation of building and construction in the residential areas of Aden City during the stage (1990 till now).

3. The Yemeni building legislations and their most important negative aspects.

4. The situation of building and construction in the residential areas of some models Arab cities under building laws and legislations.

5. The lessons that are learnt from the previous models to improve building laws in the residential areas of Aden City.

6. Results and recommendations. 